\title{
POLITICAL RISK, INFORMATION AND CORRUPTION CYCLES: EVIDENCE FROM RUSSIAN REGIONS
}

\author{
Oleg Sidorkin \\ Dmitriy Vorobyev
}

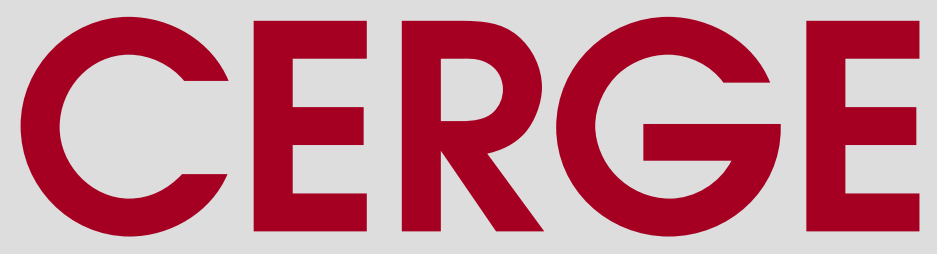




\title{
Working Paper Series 539 (ISSN 1211-3298)
}

\section{Political Risk, Information and Corruption Cycles: Evidence from Russian Regions}

\author{
Oleg Sidorkin \\ Dmitriy Vorobyev
}

CERGE-EI

Prague, May 2015 
ISBN 978-80-7343-344-4 (Univerzita Karlova. Centrum pro ekonomický výzkum a doktorské studium)

ISBN 978-80-7344-336-8 (Akademie věd České republiky. Národohospodářský ústav) 


\title{
Political Risk, Information and Corruption Cycles: Evidence from Russian Regions ${ }^{1}$
}

\author{
Oleg Sidorkin $^{2} \quad$ Dmitriy Vorobyev ${ }^{3}$
}

\begin{abstract}
Political budget cycles are a well-established phenomenon in which opportunistic politicians systematically adjust public policies prior to elections in order to attract a higher number of votes. We show that corrupt behavior of politicians also follows certain patterns, which are driven by electoral cycles. Based on Business Environment and Enterprise Performance Survey data, exploiting variation in the dates of surveys and in length and starting date of Russian regional governors' terms, we find that corruption levels, as perceived by firms operating in different regions of Russia, increases closer to the expected expiration date of a regional governor's term. We argue that the Russian political system allows governors to accumulate private information about their likelihood of remaining in office for another term. Therefore, they will know well in advance of elections if they continue in the office for the next term. We suggest that the accumulation of such information may serve as an explanation for the observed pattern of perceived corruption: if a governor gradually learns that he is leaving office once the current term has expired he has increasing incentives to engage in corrupt activities in order to accumulate wealth before he is out of the game. We formalize this idea with a simple theoretical model and test it. We find that in regions where incumbent governors are less likely to remain in office for the next term, corruption increases over their terms, while in regions where governors are more likely to remain in office, perceived corruption follows a decreasing trend.
\end{abstract}

Keywords: corruption, political budget cycle, Russia

JEL classification: D73, O17, P26

\footnotetext{
${ }^{1}$ The work on this study was supported by an individual grant N 13-0512 from the Economics Education and Research Consortium, Inc. (EERC), with funds provided by the Global Development Network and the Government of Sweden All remaining errors in this text are the responsibility of the authors.

We would like to thank Michael Alexeev, Stepan Jurajda, Patrick Gaulé, Jan Hanousek, Joaquin Artes and participants of EERC research workshops for useful comments.

${ }^{2}$ CERGE-EI, a joint workplace of Charles University in Prague and the Economics Institute of the Academy of Sciences of the Czech Republic, Politických vězňů 7, 11121 Prague, Czech Republic Email: Oleg.Sidorkin@cerge-ei.cz

${ }^{3}$ (corresponding author) Ural Federal University, Ekaterinburg, Russia and CERGE-EI, a joint workplace of Charles University in Prague and the Economics Institute of the Academy of Sciences of the Czech Republic, Politických vězňu 7, 11121 Prague, Czech Republic. Email: Dmitriy.Vorobyev@cerge-ei.cz
} 


\begin{abstract}
Abstrakt
Politicko-rozpočtové cykly jsou dobře zavedené jevy, při kterých oportunističtí politici systematicky upravují veřejné politiky před volbami s cílem získat větší počet hlasů. Ukazujeme, že zkorumpované chování politiků také sleduje určité modely, dané volebními cykly. $\mathrm{Na}$ základě mezinárodního průzkumu podnikatelského prostředí a podnikové výkonnosti (BEEPS), s využitím časové variace dat $\mathrm{v}$ průzkumech a variace $\mathrm{v}$ délce a termínu zahájení vládního období ruských gubernátorů, zjištujeme, že se úroveň korupce, tak jak je vnímána firmami, které působí $\mathrm{v}$ různých oblastech Ruska, zvyšuje blíže $\mathrm{k}$ předpokládanému datu ukončení funkčního období gubernátora. Tvrdíme, že ruský politický systém umožňuje gubernátorům shromažd’ovat soukromé " informace o pravděpodobnosti jejich setrvání v úřadu na další období, a to v dostatečném předstihu před volbami. Ukazujeme, že akumulace takových informací může sloužit jako vysvětlení pro pozorované jevy vnímané korupce: jestliže gubernátor postupně zjistí, že po vypršení aktuálního volebního období opustí úřad, jeho motivace zapojit se do korupčních aktivit se zvyšuje kvůli shromažd'ování bohatství předtím, než bude mimo hru. Tuto myšlenku formalizujeme pomocí jednoduchého teoretického modelu a testujeme ho. Zjistili jsme, že v oblastech, kde je méně pravděpodobné, že úřadující gubernátoři zůstanou ve funkci na další období, se korupce v jejích funkčním období zvyšuje, zatímco $\mathrm{v}$ regionech, kde je větší pravděpodobnost, že gubernátoři zůstanou ve funkci, vnímaná korupce vykazuje klesající trend.
\end{abstract}




\section{Introduction}

There is a plentiful evidence which shows that politicians change their behavior during their terms of office in a systematic way, and these changes are substantially driven by the approach of elections. In order to increase the chance of re-election, incumbents in pre-election periods tend to increase public expenditures, change the composition of expenditures towards more visible projects and even release overly optimistic economic forecasts. In this paper we examine whether there is any pattern in corrupt behavior of politicians that can be explained by political cycles.

Opportunistic behavior of politicians is empirically well documented for both developed and developing countries. Though there is some degree of controversy, the literature on political budget cycles is generally consistent in its major findings. In developing countries, cycles in fiscal policies are usually of higher magnitude and often rewarded by voters (Akhmedov and Zhuravskaya, 2004; Guo, 2009). In developed countries, cycles in the levels of public expenditures appear much more rarely, are of a smaller magnitude, and can even be punished by voters Shi and Svensson, 2006. Brender and Drazen, 2008). Usually, in developed countries, budget cycles take the form of temporary changes in composition of public expenditures with shifts towards more visible projects in pre-election years $($ Brender, 2003; Schneider, 2009; Drazen and Eslava, 2010; Aidt et al., 2011).

There are several theoretical explanations for the existence of such cycles. Early works simply assume that voters are naive: they interpret the pre-election performance of incumbent as a result of his competency and reward him with additional votes in elections (Nordhaus, 1975). Rogoff and Sibert (1988) and Rogoff (1990) suggest a signaling approach to explain fiscal cycles. Their logic is that when an incumbent's competency is not observable by voters, budget cycles could be used by politicians as a signaling device to reveal their competency. Specifically, a highly competent incumbent increases public expenditures prior to elections to a higher than optimal level to signal his competence, at the expense of debt to be paid after elections. Since for an incumbent with low competence such a deviation from optimal fiscal strategy is too costly, voters 
would immediately infer high competence from high public expenditures in the preelection period and thus vote for the incumbent. Shi and Svensson (2006) as well as Martinez (2009) show that asymmetric information about an incumbent's competency may generate incentives to finance extra government expenditures through excessive borrowing in pre-election periods, even if voters do not electorally reward such behavior. In their models voters cannot infer an incumbent's competency (in fact productivity) from the amount of public good provided (which is determined by both competency and available financial resources: a more competent incumbent could provide more public good given the level of expenditures), and thus can only form rational expectations about this. Because of increasing marginal costs of borrowing, an incumbent is likely to have an incentive to excessively borrow prior to elections even though voters would rationally anticipate this.

In this paper we investigate whether there are cycles of a similar nature in corrupt behavior of politicians. Intuitively, the proximity of elections may have an effect on corrupt behavior similar to that on fiscal behavior: if voters appreciate a politician's integrity, the incumbent may want to commit less corruption prior to elections in order to attract extra votes, for the same reasons he adjusts fiscal policies. In this research we argue that there may be other mechanisms through which proximity of elections can affect politician's incentives for corruption, try to identify them, and quantify their effects.

There is no need to emphasize that corruption is an undesirable phenomenon. Negative consequences of corruption on various social, economic and political aspects are well studied in the academic literature; theoretically, empirically and experimentally, on both macro and micro levels. Corruption misallocates resources and human capital, distorts income and wealth distribution, decreases levels and quality of investments, shifts government expenditures towards less transparent directions, increases transaction costs, generates wasteful resource expenditures, slows down economic growth, etc. (see, for example, Jain (2001); Rose-Ackerman and Soreide (2011) for comprehensive reviews). There are many factors that have a strong impact on corruption: value 
of rents, deterrents to corruption, quality and strength of legislation, society's moral values, and many others. Political institutions are also included among these factors.

Scholars distinguish two main channels through which political institutions may create a space for corruption. First, political institutions differ in their ability to prevent corrupt candidates from being elected to positions of power. A large body of research studies the link between electoral legislation in addition to properties of electoral mechanisms and corruption (see, for example, Myerson (1993); Persson et al. (2003)). Another channel through which political institutions are linked to corruption is a lack of accountability, which may increase politicians' corruption incentives. When accountability is low, a politician in office bears a relatively low risk of being punished, either directly by law or indirectly through the probability of not being reelected, and thus has stronger incentives to engage in corrupt activities which generate private benefits. Low accountability itself may come from various sources, ranging from properties of electoral systems (e.g.Persson et al. 1997, 2003)) to lack of qualified public control over in-office politicians. Our research is also aimed at contributing to the understanding of how features of political institutions affect politicians' corruption incentives.

In this paper we establish certain patterns in corrupt behavior of politicians which can, to some extent, be explained by political cycles. We use a dataset on Russian regions based on the Business Environment and Enterprise Performance Survey (BEEPS) to estimate the effect of the approach of expiration dates of regional governors' terms on the level of corruption anticipated by local firms. We first find that pressure on business for corruption increases on average $\oint^{1}$ closer to the incumbent's term expiry date. This result is consistent with a recent and, to our knowledge, the only study on the relationship between corruption and political cycles in Russia, by Mironov and Zhuravskaya (2014). Using banking transaction data, they show that the amount of illegal cash outflow (measured as transfers to fly-by-night firms) of Russian firms that

\footnotetext{
${ }^{1}$ Since our data do not allow us to distinguish between true corruption and reported corruption, which may not be the same things, the expressions "corruption increases", "firms report higher corruption", "firms perceive higher corruption", and "governors put more pressure on business" should be understood as equivalent throughout the paper.
} 
obtain public procurement contracts strongly increases around regional elections. This can be explained only by corruption, since the firms that do not obtain public procurement contracts do not exhibit a similar cycle. Neither is such a cycle found in the legal activities of the firms.

Despite being consistent with studies on corruption in Russia, the result established in our paper does not accord with patterns in fiscal behavior of politicians found in the literature on political business cycles: if voters appreciate politicians' integrity incumbents should decrease corruption closer to the expiration of their terms rather than increase it. We argue that some features of the political system in Russia significantly decrease the "vote attracting" effect of changes in corrupt behavior and thus there must be some other reasons for the observed pattern. We suggest that the pattern we find can be explained by the risk of losing office faced by the governors, together with private information regarding their future which they accumulate during their terms. Further, we discuss that the Russian political system allows governors to know well in advance whether they will keep their office for the next term or not. If a governor knows that he is leaving office once the current term is expired, he has higher incentives to engage in corruption activities in order to accumulate wealth before he is out of the game. If he gathers this information gradually over his term, then he would increase pressure for corruption on local business over time. Contrariwise, if a governor knows that he will keep the office for the next term he may have incentives to accumulate wealth through corruption smoothly and thus not increase, or even decrease, his corrupt pressure while he becomes more certain that he is staying for the next term ${ }^{2}$.

We formalize this idea with a simple theoretical model and then test it using several approaches. Though the data we use do not allow us to directly verify the existence of the relationship between governors' beliefs and their corrupt behavior, we are able to

\footnotetext{
${ }^{2}$ Throughout the paper, we mainly talk about corrupt behavior and the incentives of governors, though obviously a governor is not the only person in a region who generates corrupt pressure on local business. In each region there are a lot of other local officials who are able to extract rents. However, regional governors in Russia usually have strong control over the actions of other officials in the region and their careers, and it is usual practice that a governor's resignation results in the consecutive resignation of his core team and affiliated state officials. As a result, we believe that the approach of expiration of a governor's term generates incentives to corruption for local officials similar to those of the governor himself.
} 
implement some indirect tests which are all consistent in their results: those governors who are less likely to remain in office for the next term tend to put more pressure on business for corruption over time, in contrast to those who are more likely to remain in office.

\section{Methodology}

\subsection{Background}

In 1993, when the current Constitution of Russia was adopted, there were 89 constituent entities ("federal subjects") in the country "which shall have equal rights" according to Article 5 of the Constitution. Between 2003 and 2007 several mergers of the entities took place, and since then there have been 83 federal subjects in Russia, including 21 "republics", 9 "krays", 46 "oblasts", 2 "cities of federal significance", 1 "autonomous oblast" and 4 "autonomous okrugs". For simplicity, we will refer to all of them as "regions" throughout the paper. Since Russia became an independent state following the collapse of the Soviet Union, mechanisms of selecting governors ("gubernators") of the regions were very mixed across federal subjects: in some regions governors were elected directly by the population, in others they were appointed by regional parliaments or by the President of Russia. Since 1996, following the decision of the Constitutional Court of Russia, governors of all the federal subjects had to be directly elected by population.

At the end of 2004 the President of Russia, Vladimir Putin, proposed a reform that abolished direct gubernatorial elections: since that time regional governors have been appointed by the president. Though formally the new procedure assumed that the president just nominates a candidate for governor while the regional parliament can approve or reject the candidate, there was no single case since 2004 when the parliament of a region did not approve a presidential nominee. The reform was approved by the Parliament of Russia ("State Duma") in December 2004. Because the reform assumed

the replacement of elected governors after expiration of their terms, and the date 
of expiration varied significantly across the regions, the full replacement of elected governors took about five years. The first appointed governor took office in February 2005, while the term of the last elected governor expired in December 2009, and since that time all the governors were appointed until October 2012. The variation in the dates of gubernatorial appointments across the regions can be mainly explained by differences in local legislation that allowed for different term lengths (usually four or five years) as well as a high degree of freedom for regions in setting the dates of gubernatorial elections in the past. Because of this, we believe that the variation in the dates of governors' appointment and, thus, in the dates of the expiration of their term across regions can be considered as exogenous.

\subsection{Data}

We use data on Russian firms from two waves of the EBRD/World Bank Business Environment and Enterprise Performance Survey (BEEPS) conducted in 2008-2009 (wave IV) and 2011-2012 (wave V) $)^{3}$. Both waves provide data on about 5,000 firms in 37 Russian regions (over 1,200 firms from 22 regions in the first wave and over 3,700 firms from 37 regions in the second wave). They contain firm-level characteristics such as industry, owner's origin, number of employees, age, manager's characteristics and the date the firm was surveyed. According to the description of the BEEPS dataset, the authors of the survey did their best to make the sample of the surveyed firms representative.

The main variable for our analysis comes from the Likert scale's question "Is corruption an obstacle to the current operations?", the answers to which range from "no obstacle" (0) to "very severe obstacle" (4). We label the main variable as Corrupt. Despite a possible caveat of subjectivity, we believe that this measure of business sector corruption is the most suitable for our analysis, as firms report their corruption perception even if they are not involved in corruption activities themselves.

We also use an alternative indicator of corruption which BEEPS offers: we use

\footnotetext{
${ }^{3}$ Three earlier waves of the survey do not contain information on regions where the surveyed firms operate, and, thus cannot be used for the purposes of our analysis.
} 
answers to the questions "On average, what percent of total annual sales, or estimated total annual value, do establishments like this one pay in informal payments or gifts to public officials to "get things done" (see Figure 5 in the Appendix for the precise survey form). We label this variable as CorSale. Though this variable may seem to better reflect actual corruption and be more appropriate for the purposes of our analysis due to their continuous nature, we should treat answers to these questions with care. In our dataset, only $72.7 \%$ of the respondents answered the question at all, and only $14.4 \%$ of those who answered (521 observations) reported positive informal payments for the CorSale question. One reason for such a result may be that the respondents are reluctant to talk about corruption in which they are directly involved. In contrast, $61.8 \%$ of respondents reported that corruption is an obstacle to current operations (from minor to very severe). Another possible problem with the alternative measure is that answers to this question depend heavily on the knowledge of the individuals surveyed, and thus may be subject to severe measurement error. Moreover, this measure does not account for any form of corruption which is not directly related to informal payments, while our main corruption measure does. Thus, throughout our analysis, we use the categorical variable Corrupt as the main measure of perceived corruption, and, as a robustness check, present some results using CorSale as an alternative measure, showing that our main findings are quite similar for both measures.

We also collect data on various characteristics of executive authorities of the regions such as age and length of tenure in office. We complete our dataset with political and economical characteristics of the regions where the firms from the BEEPS dataset operate, including GRP, population, inflation index, unemployment rate, number of state officials, etc. To control for historical regional corruption levels we use the corruption index for Russian regions in 2000-2004 by the Moscow Carnegie Center (Petrov and Titkov, 2004). Please see Tables 7,11 for the complete list of variables used in the analysis. Our final dataset contains data on 4974 firms operated between 2008 and 2012 in 37 Russian regions across 27 industries. 


\subsection{Identification}

We want to test the hypothesis that the approach of the expected expiration date of the term of office influences corrupt behavior of executives. For this purpose, we estimate the following model:

$$
\text { Corrupt }_{i r}=\alpha_{0}+\alpha_{1} \text { Time }_{i r}+\alpha_{2} \text { Time }_{i r}^{2}+\alpha_{z} \text { Controls }_{i r}+u_{i r}
$$

where Time $_{i r}$ is the share of current term of a governor of region $r$ where firm $i$ operates completed by the moment of the survey. For instance, if a firm $i$ from region $r$ was surveyed on the day when the governor of the region has just started his current term, Time $_{i r}=0$; if it was surveyed in the last day of the governor's term, Time $i r=1$; if at the moment of the survey the governor had spent 3 years in office out of his 5 -year term, Time $_{i r}=0.6$. We use percentages to measure time passed since the beginning of the current governor's term till the moment of survey instead of days, weeks or months because of the variation in term length across regions of Russia: in some regions the governor's term length is 4 years, in others it is 5 . Using percentages allows us to make our variable of interest comparable across such regions. Time $_{i r}^{2}$ is a quadratic term for Time $i r$; Controls $s_{i r}$ is other control variables for regional, governor's and firmsćharacteristics as well as year dummies; $u_{i r}$ is the error term.

We try to find out whether corruption follows some pattern over governors' terms. Our main variable of interest is Time $_{i r}$. We expect that the pattern may be non-linear and include a quadratic term for Time $i_{i r}$. Variation in Time ${ }_{i r}$ comes from several sources. First, as discussed above, the dates of governors' term expiration across Russian regions vary greatly due to historical reasons as well as differences in regional electoral legislation. Second, dates of the survey in each wave vary substantially both across regions and, within a region, across firms. For example, for 16 out of 37 regions in our dataset there are observations for each of the 4 survey years $(2008,2009,2011$ and 2012), and the dates of firms' survey within the same wave and same region vary by up to 7 months. The kernel density of Time $_{i r}$ is presented in Appendix, Figure 4. 
Unfortunately, wave IV and wave V BEEPS data for Russia are based on a stratified random sample of firms, such that only 128 firms are present in both waves. This does not allow us to construct true panel data, so we are limited to cross-section estimation methods with dummy variables for years of the survey and mean-based pseudo-panels where we can group data by regions since in most cases we observe similar regions in both waves. First, we estimate the empirical model (1) on pooled cross-sectional data, with Corrupt and CorSale as dependent variables, by several methods. We run an ordinary least squares regression and logistic regression with a binary variable which takes 0 value in case of no corruption perceived by firms and 1 otherwise, for both dependent variables. Then we run an ordered logistic regression for the categorical variable Corrupt. Since the ordered logistic regression assumes that coefficients are the same for different categories and error variances are homoskedastic, and we suspect that these assumptions may be violated, we also estimate a stereotype logistic regression (SLogit) and ordinal generalized linear (OGLM) model, which do not impose the proportional odds assumption. We also estimate a two-part model (a generalized version of a Tobit model) for the CorSale dependent variable, which assumes that zero and positive outcomes are generated by different underlying decisions, since this is likely to be the case with the CorSale corruption measure. It models a decision to participate in corruption activities by Logit and then models corruption intensity by the generalized linear model. Since error terms for firms are likely to be correlated within regions, in all the estimations we use corresponding clustering.

Then we try to partially overcome the identification problems implied by the crosssectional nature of the data and construct a group-mean pseudo-panel for our dataset. The idea of group-mean pseudo-panels, originally suggested by Deaton (1985), is to identify cohorts in the data and then to follow cohort means over time. As the BEEPS survey follows a stratified design with respect to regions, we may use regions to construct group-mean pseudo panel cohorts.

Though there are certain issues with using pseudo-panels, such as biased estimates and measurement errors under certain circumstances, they generally make it possible 
to obtain consistent estimates when individual effects are correlated with explanatory variables, as with genuine panel data (see Collado (1997), McKenzie (2004), and Verbeek (2008) for a discussion on the consistency of pseudo-panel estimates).

Following Verbeek (2008), the basic pseudo-panel model with repeated observations over $T$ periods and $C$ cohorts (groups) is as follows:

$$
\bar{y}_{c, t}=\bar{x}_{c, t}^{\prime} \beta+\bar{\alpha}_{c, t}+\bar{u}_{c, t}, \quad c=1, \ldots, C ; \quad t=1, \ldots, T
$$

where $\bar{y}_{c t}$ - is the average value of all observed $y_{i t}$ 's in group $c$ in period $t$, and similarly for other variables.

If we treat the cohort-specific effect $\bar{\alpha}_{c, t}$ as fixed unknown parameters and assume that there is no variation over time, that is $\bar{\alpha}_{c, t}=\alpha_{c}\left(\bar{\alpha}_{c, t} \rightarrow \alpha_{c}\right.$ if $\left.n_{c} \rightarrow \infty\right)$, we can estimate the above model by within estimator. We apply both fixed-effects estimation (assuming that the cohort-specific effect is correlated with independent variables) and random-effects estimation (applying a stricter assumption that the cohort-specific effect is uncorrelated with the independent variable). Since this approach requires a large number of individual observations per cohort, while we have a few hundred on average, we may encounter a small-sample bias problem, so we treat the approach as an additional robustness check rather than the main test of our hypothesis.

We also estimate our model using two-way cluster-robust standard errors on regions and years of the survey, suspecting that error terms for firms may be correlated within a year. We modify our analysis to account for this, but do not find significant differences. The results for the modified analysis are available upon request.

\section{Results}

The main results for Corrupt are presented in Tables 1 and 2 in the Appendix. All the regressions for Table 1 provide similar results in terms of significance and the direction of the effect, although interpretation is somewhat different. Standard errors are clustered on regions. We use an OLS estimation (column 1, Table1) for illustration 
purposes only, since there are obviously several difficulties with the OLS estimation in our case. First, errors are likely to be heteroskedastic and not normally distributed. Second, the results of the OLS estimation would correspond to ordered models when the thresholds are about the same distance apart, while this is likely not to be the case, and thus OLS can give very misleading results (Long, 1997).

Logit (all observations with non-zero reported corruption perception are combined into value 1 to construct a binary variabl $\rfloor^{4}$ and an ordered logistic regression provides similar results for Time $_{i r}$ and Time $_{i r}^{2}$ in terms of log odds (column (2) and column (3) of Table 1). Since the Logit equation ignores additional information on intensity of corruption, we use an ordered logistic regression.

We test the parallel regression assumption for ordered logistic regressing using a Brant test. The statistic of this test is not significant at conventional levels for Time ir $_{\text {r }}$ and $\operatorname{Time}_{i r}^{2}$, implying that we do not find evidence that the parallel regression assumption may be violated for these variables. At the same time, for several other variables there is evidence that this assumption may be violated, so we try alternative models which can account for this problem. We use stereotype logistic regression (SLogit), which does not impose the constraint of parallel regression. In addition, we use an ordinal generalized linear (OGLM) model to specify determinants of heteroskedasticity explicitly, in an attempt to correct for it. Our results for SLogit and OGLM(column (1) and (2) of Table 2 respectively) suggest that the main conclusions in terms of directions, magnitude of effects and significance do not change substantially and that the ordered logistic regression model provides reasonable estimates (when we compare models using BIC and AIC criteria, the statistics provide little evidence that any of these models should be preferred).

Overall, our results show that the approach of the expiry date of the governor's term and perception of corruption by local business are strongly related. The effect of the term completion share $\left(\right.$ Time $\left._{i r}\right)$ is statistically significant at the $1 \%$ level. The results

\footnotetext{
${ }^{4}$ As a robustness check, we also combine the binary variable in a different way: for Corrupt we combined the categories "no obstacles" and "minor obstacle" as 0 , and all other categories as 1 . The results are similar, and available from authors by request.
} 
also suggest that this effect is likely to be non-linear, since the quadratic term Time $_{i r}^{2}$ is also significant at the $1 \%$ level. To illustrate the dynamics of corruption perception over a governor's term we construct, based on our estimates, predicted probabilities to observe each value of the variable Corrupt as a function of Time. The probabilities are presented in Figure 1 .

The predicted probability of low corruption perception ("no obstacle" to current operations) demonstrates a clear inverse U-shaped profile and decreases substantially towards the expected end of a governor's term, while the pattern for higher perception of corruption ("major" and "very severe" obstacle to current operations) is exactly the opposite. The graphs suggest that firms on average perceive higher pressure for corruption at the beginning and end of the political term. In quantitative terms, the predicted probability of zero-corruption perception ("no obstacle") decreases from about 0.58 to 0.4 between $50 \%$ to $100 \%$ of the term completion, while the probability of high corruption ("very severe") increases from about 0.06 to 0.11 for the same period.

For the alternative measure of corruption, share of sales a firm pays as bribes, labeled as CorSale, we identify a very similar pattern. The results of the estimations are presented in Table 3 . It is necessary to point out that the distribution of the dependent variable CorSale is far from being normal because of the presence of excessive zeroes. This skewness can possibly cause severe problems with the OLS estimation (column (1) of Table 3), so we prefer to focus on the results of logistic regression, where we combine all the values of the dependent variable into two groups, zeros and positive values (column (2)), and a two-part model (column (3)). The Logit results for Time ir are in line with the main results for the dependent variable Corrupt in terms of effects' direction, although magnitudes of the effects differ slightly. The two-part model estimates demonstrate that the results for the CorSale come mainly from corruption participation (Logit), but not from the corruption intensity (GLM). This may come from the fact that CorSale variable is noisy, and its true value heavily depends on the truthfulness of respondents, among other concerns. To illustrate the dynamics of corruption, measured as the share of sales firms pay as bribes, we construct a graph 
of predicted probability to observe a positive value of the corruption measure as a function of term completion share (Time). The corresponding chart is presented in Figure 1.

In the final step, we estimate the effect of term completion on corruption based on pseudo-panel data. As we discussed above, our data do not allow us to perform the usual panel data analysis, since there are very few firms that we observe in more than one wave of the survey. However, since we observe firms operating in the same regions in both waves, we can construct group-mean pseudo panels, using regions as groups, and analyze the resulting data set with the usual panel data techniques. The results of fixed-effects and random-effects are presented in Table 4. Although they are consistent with previous results, one needs to keep in mind that, as discussed in the previous section, the estimates can be biased due to the relatively small data sample.

The liner predictions of corruption value by different level of Time after fixed effects and random effects regression are presented in Figure 2. The dynamics are fully in line with our previous results: pressure for corruption increases towards the expected end of term. In addition, we perform a Hausman test: random effects versus fixed effects model, with the null hypothesis that the preferred model is random effects. The test's statistic $\chi^{2}(14)=16.37$ suggests that we cannot reject the hypothesis that errors and explanatory variables are not correlated, and thus we can use the random effects model as more efficient.

One might be concerned that the pattern we have established may come from the nature of the corruption measure we used rather than from the corrupt behavior of politicians, since corruption perception may generally fluctuate over a governor's term due to reasons other than actual changes in his corrupt behavior. For instance, corruption perception may increase around re-appointment time as a result of more intense news coverage, media campaigns and political rivals. However, this is unlikely to be a problem for our analysis for two reasons. First, the question, answers to which we use to construct our main dependent variable, is not purely managers' perception of corruption, but their perception of obstacles for their business as a consequence of 
corruption, which is unlikely to be easily altered by e.g. media without the presence of an actual effect on business. Second, we find the same pattern using the alternative corruption measure (CorSale), which is much more objective and much less sensitive to information flows that may be generated by media and political rivals around the expiration of the governor's term. Hence, we believe that the established pattern is likely to reflect the pattern in actual corrupt behavior rather than just in perception of corruption.

There are several other variables, other than the variable of interest, which also have a significant effect on corruption perception. For instance, a dummy for a top manager being a woman (Female) is statistically significant and negative for all the specifications, suggesting that firms under female managers tend to either perceive or report lower corruption. Also, in all the specifications, dummies for 2011 and 2012 have a strong negative impact on dependent variables. This may indicate either a general trend of decreasing corruption in Russia or growing tolerance of corruption over time. Furthermore, for most of the specifications there is weak evidence that in regions where the ruling party "United Russia" has stronger support, measured as the vote share it received on the 2007 Parliamentary elections, as well as in regions with lower turnout in the 2007 elections, firms tend to perceive higher corruption. One explanation for such results may be electoral integrity, which is often doubted in contemporary elections in Russia: those governors who have stronger control over local business may also have stronger control over local electoral commissions and thus are more likely to deliver higher results for the ruling party, while citizens are less willing to participate in elections they expect to be fraudulent.

\section{Understanding Corruption Cycles}

We have established that perceived corruption in Russia follows a pattern that can be explained by electoral cycles. Specifically, we observe that firms tend to experience more pressure for corruption closer to the expiration of terms of local governors. As 
discussed above, this pattern cannot be explained by reasoning used in the political budget cycles literature for rationalizing systematic changes in the fiscal behavior of politicians in office, where the main idea is that politicians adjust their behavior in a way that may give them additional votes in upcoming elections. Moreover, such reasoning is unlikely to be appropriate at all for the system existing during the time period considered in our analysis which assumes the appointment, rather than election, of regional governors. Due to the nature of the Russian political environment, such a system of appointment is likely to be much less sensitive to politicians' corrupt behavior than an electoral system: a governor's chances for re-appointment depends not only on performance in sectors valued by society, as it would be in the case of direct elections, but also substantially on personal relationships and loyalty to the president.Reuter and Robertson (2012), studying an extensive dataset on Russian governors, find that while governors' loyalty to the president and, more specifically, their ability to mobilize votes for the ruling party, have a strong impact on appointment decisions, good governance, measured as regional economic development, plays a limited role in appointments. Though it seems that avoiding corruption closer to the re-appointment decision could give a governor stronger support among citizens and thus push the President towards a decision in favor of the governor, it does not appear to be an effective strategy in Russia. This feature of the Russian political system significantly decreases, though we cannot claim that it completely eliminates, "vote attraction" incentives: The Russian appointment system is more tolerant to corrupt governors in terms of chances of remaining in office than an electoral system. As a result, incumbents are unlikely to significantly decrease their engagement in corruption prior to expiration of their term in order to obtain a reward in terms of increased chances for re-appointment. Thus, there must be an alternative explanation for the pattern in corrupt behavior we have established.

We suggest that this pattern can be driven by the governors' risk of not being reappointed for the next term together with their private information about the likelihood of remaining in office. Our hypothesis is that at the beginning of their terms governors 
may not be very certain about whether they will remain in office for the next term or not, but throughout the term, they accumulate some information that changes their beliefs and at some point, well in advance of the actual end of the term, governors are quite confident about the president's re-appointment intentions. These changes in beliefs may be a result of, for example, information that comes directly from the president and people from the resident's circle, or may be driven by political news and rumors, etc.

It is likely that the accumulation of the information forces governors to adjust their corruption behavior. Whenever a governor becomes more certain that he keeps the office for the next term he may have incentives to smooth pressure for corruption over time and thus not to increase corruption closer to his term expiration. But if a governor believes that he is leaving the office, he would increase pressure for corruption in order to extract rents which will not be available once he is out. We formalize this idea in the next section using a simple theoretical model.

Then we are able to test this model. One crucial thing about our data is that we observe what eventually happened to the majority of governors (whether they stayed for the next term or left) 5 . Assuming that governors possessed correct, at least on average, information about their future some time in advance, we perform our analysis separately for firms operated in regions where governors left once their terms had expired and for those operated in regions where governors stayed for another term. If our theory is valid, we should observe increasing corruption over terms in the first case, while we should not in the second case. Then, we use governors' meetings with the president in the last year of their terms as a proxy for the moment of uncertainty resolution, or at least a substantial change in beliefs, assuming that at such meetings the president tends to disclose, fully or partially, his intentions towards the governors' reappointment. Under this assumption, one should observe that those governors who left office at the end of their term, put more pressure on business after a meeting with the president then they had done before. In the final section of this paper we

\footnotetext{
${ }^{5}$ Some of the governors considered in our study have not yet finished their terms.
} 
demonstrate that this is precisely the case.

\subsection{Theoretical Model}

Consider an incumbent who lives for three periods. In each period, while in office, the incumbent can engage in corrupt activities and extract corruption benefits $(x)$ at increasing marginal costs. Denote the cost function $c(x)$. The incumbent derives utility $U(x)$ from corruption rent consumed, where $U$ is a standard concave utility function. There is no time discounting. In the first two periods the incumbent is in office, but whether he keeps it for the third period depends on the president's re-appointment decision, made at the end of the second period. If the president decides not to reappoint, the incumbent leaves the office, and cannot extract corruption rents anymore. At the beginning of the first period the incumbent believes that the probability of his re-appointment is $p$. In the end of the first period he gets a perfectly informative signal, and since that he knows for sure whether he stays for the third period or leaves the office after the second period.

Consider the incumbent's problem. Every period he decides how much corruption rent to extract $(x)$ and how much to consume $(y)$ or save $(s)$ for the future. First, consider the incumbent's decision after the first period, when he has learned whether he remains in office for the third period or not. Since in the third period the incumbent consumes everything he is left with, and second period savings are simply the difference between extracted and consumed rent, the incumbent decides in fact how much rent to extract in each period $\left(x_{2}\right.$ and $\left.x_{3}\right)$ and how much to consume in the second period $\left(y_{2}\right)$, given savings from the first period $\left(s_{1}\right)$. Thus, the incumbent solves:

$$
\max _{x_{2}, x_{3}, y_{2}} U\left(y_{2}\right)-c\left(x_{2}\right)+q U\left(x_{2}+x_{3}+s_{1}-y_{2}\right)-q c\left(x_{3}\right)+(1-q) U\left(x_{2}+s_{1}-y_{2}\right),
$$

where $q \in\{0,1\}$ is the probability to be re-appointed.

First-order conditions then are:

$$
\left[x_{2}\right]:-c^{\prime}\left(x_{2}\right)+q U^{\prime}\left(x_{2}+x_{3}+s_{1}-y_{2}\right)+(1-q) U^{\prime}\left(x_{2}+s_{1}-y_{2}\right)=0
$$




$$
\begin{gathered}
{\left[x_{3}\right]: q U^{\prime}\left(x_{2}+x_{3}+s_{1}-y_{2}\right)-q c^{\prime}\left(x_{3}\right)=0} \\
{\left[y_{2}\right]: U^{\prime}\left(y_{2}\right)-q U^{\prime}\left(x_{2}+x_{3}+s_{1}-y_{2}\right)-(1-q) U^{\prime}\left(x_{2}+s_{1}-y_{2}\right)=0}
\end{gathered}
$$

Suppose the signal was positive, i.e. $q=1$. Denote the solution for the maximization problem (3) $\left(x_{2}^{*}, x_{3}^{*}, y_{2}^{*}\right)$ in this case. From conditions (4) and (5) it immediately follows that $x_{2}^{*}=x_{3}^{*}$, and $y_{2}^{*}=x_{2}^{*}+s_{1} / 2$. Consumption in the third period is then $y_{3}^{*}=x_{2}^{*}+s_{1} / 2$. Obviously, if the incumbent knows that he will remain in office for the third period, in each (second and third) period he would extract the same amount of rent as a result of increasing marginal costs, consume everything he extracted plus exactly half of the savings from the first period to smooth consumption as a result of concave utility function.

For the case when the signal is negative, meaning that $q=0$, denote solution $\left(\hat{x}_{2}, \hat{x}_{3}, \hat{y}_{2}\right)$. Then the first-order conditions imply that $\hat{y}_{2}=\frac{\hat{x}_{2}+s_{1}}{2}$. Clearly, if the incumbent is not keeping the office for the third period he consumes exactly half of what he has in the second period (extracted rents plus savings) and saves the other half for the third period to smooth his consumption, i.e. $\hat{y}_{3}=\hat{y}_{2}$.

Recall the conditions that define equilibrium values of the second period consumption for each signal realization:

$$
\begin{gathered}
U^{\prime}\left(x_{2}^{*}+s_{1} / 2\right)=c^{\prime}\left(x_{2}^{*}\right) \\
U^{\prime}\left(\hat{x}_{2} / 2+s_{1} / 2\right)=c^{\prime}\left(\hat{x}_{2}\right)
\end{gathered}
$$

Given the properties of $U(x)$ and $c(x)$ it must be the case that $\hat{x}_{2}>x_{2}^{*}$, i.e. if the incumbent is going to leave the office he extracts more corruption rent in the period preceding his term expiration than if he is keeping his office for the next term.

Consider then the first period problem, when the incumbent does not know for sure 
whether he would remain in office for the third period, but knows that he will receive a perfectly informative signal after the first period. In fact, the probability of receiving a signal suggesting that he is staying, from his point of view is exactly $p$, his prior probability of being re-appointed. The incumbent decides how much rents to extract, to consume and to save in the first period:

$$
\begin{aligned}
& \max _{x_{1}, y_{1}} U\left(y_{1}\right)-c\left(x_{1}\right)+p\left(U\left(y_{2}^{*}\right)-c\left(x_{2}^{*}\right)+U\left(x_{1}+x_{2}^{*}+x_{3}^{*}-y_{1}-y_{2}^{*}\right)-c\left(x_{3}^{*}\right)\right)+ \\
& \quad+(1-p)\left(U\left(\hat{y}_{2}\right)-c\left(\hat{x}_{2}\right)+U\left(\hat{y}_{3}\right)\right) .
\end{aligned}
$$

Using all the relationships between the second and the third period equilibrium values of corruption, consumption and savings, the optimization problem can be rewritten as follows:

$$
\begin{gathered}
\max _{x_{1}, y_{1}} U\left(y_{1}\right)-c\left(x_{1}\right)+2 p\left(U\left(x_{2}^{*}+\frac{x_{1}-y_{1}}{2}\right)-c\left(x_{2}^{*}\right)\right)+ \\
+2(1-p)\left(U\left(\frac{\hat{x}_{2}+x_{1}-y_{1}}{2}\right)-\frac{1}{2} c\left(\hat{x}_{2}\right)\right) .
\end{gathered}
$$

Since both $x_{2}^{*}$ and $\hat{x}_{2}$ are functions of $s_{1}=x_{1}-y_{1}$, the first-order conditions takes the following form:

$$
\begin{aligned}
{\left[\mathrm{x}_{1}\right]: } & -c^{\prime}\left(x_{1}\right)+2 p\left(U^{\prime}\left(x_{2}^{*}+\frac{x_{1}-y_{1}}{2}\right)\left(\frac{\partial x_{2}^{*}}{\partial x_{1}}+\frac{1}{2}\right)-c^{\prime}\left(x_{2}^{*}\right) \frac{\partial x_{2}^{*}}{\partial x_{1}}\right)+ \\
& +2(1-p)\left(U^{\prime}\left(\frac{\hat{x}_{2}}{2}+\frac{x_{1}-y_{1}}{2}\right)\left(\frac{\partial \hat{x}_{2}}{\partial x_{1}}+\frac{1}{2}\right)-\frac{1}{2} c^{\prime}\left(\hat{x}_{2}\right) \frac{\partial \hat{x}_{2}}{\partial x_{1}}\right)=0 \\
{\left[\mathrm{y}_{1}\right]: } & U^{\prime}\left(y_{1}\right)+2 p\left(U^{\prime}\left(x_{2}^{*}+\frac{x_{1}-y_{1}}{2}\right)\left(\frac{\partial x_{2}^{*}}{\partial y_{1}}-\frac{1}{2}\right)-c^{\prime}\left(x_{2}^{*}\right) \frac{\partial x_{2}^{*}}{\partial y_{1}}\right)+ \\
& +2(1-p)\left(U^{\prime}\left(\frac{\hat{x}_{2}}{2}+\frac{x_{1}-y_{1}}{2}\right)\left(\frac{\partial \hat{x}_{2}}{\partial y_{1}}-\frac{1}{2}\right)-\frac{1}{2} c^{\prime}\left(\hat{x}_{2}\right) \frac{\partial \hat{x}_{2}}{\partial y_{1}}\right)=0
\end{aligned}
$$

Note that since both $x_{2}^{*}$ and $\hat{x}_{2}$ are functions of $s_{1}=x_{1}-y_{1}, \frac{\partial x_{2}^{*}}{\partial x_{1}}=-\frac{\partial x_{2}^{*}}{\partial y_{1}}$ and $\frac{\partial \hat{x}_{2}}{\partial x_{1}}=-\frac{\partial \hat{x}_{2}}{\partial y_{1}}$. Hence, from the first-order conditions it immediately follows that:

$$
U^{\prime}\left(y_{1}^{*}\right)=c^{\prime}\left(x_{1}^{*}\right)
$$


or equivalently:

$$
U^{\prime}\left(x_{1}^{*}-s_{1}^{*}\right)=c^{\prime}\left(x_{1}^{*}\right)
$$

Together with conditions (7), (8), the latter condition defines equilibrium levels of corruption (extracted rents) in the first period and in the second period for each realization of the signal.

Given the concavity of the utility function and increasing first derivative of the cost function, these conditions imply $\hat{x}_{2}>x_{2}^{*}$ and $x_{1}^{*}>x_{2}^{*}$. Moreover, it can be shown that $\hat{x}_{2}>x_{1}^{*}$. To see this, note that if the latter inequality is true it must be $U^{\prime}\left(x_{1}^{*} / 2+s_{1}^{*} / 2\right)>U^{\prime}\left(x_{1}^{*}-s_{1}^{*}\right)$, and hence $x_{1}^{*} / 2+s_{1}^{*} / 2<x_{1}^{*}-s_{1}^{*}$. The latter condition implies $s_{1}^{*}<\frac{1}{3} x_{1}^{*}$. This condition means that in equilibrium the incumbent should not save more than one third of what he extracted in the first period.

To understand why this is always the case, think of the incumbent who believes with certainty that he will not remain in office for the third period (i.e. $p=0$ ). Clearly, in this case the optimal behavior is to extract the same amount of rent in each of the first two periods and save exactly one third from these amounts for the third period to smooth the consumption. But if there is even a small probability of being present in the third period and of extracting additional rent, there is an incentive to save less in each period. Think of another extreme case, when the incumbent is certain that he is keeping the office for the third period. In this case he saves nothing in all the periods. As a result, whenever $p<1$ the incumbent saves strictly less than one third of the extracted rents in the first period, and thus $\hat{x}_{2}>x_{1}^{*}$.

The derived relationships between $x_{1}^{*}, x_{2}^{*}$, and $\hat{x}_{2}$ are sufficient to draw the corruption profile over the incumbent's term. The incumbent who is expecting not to be re-appointed for the next term increases pressure for corruption over time, while the incumbent who is going to remain in office for the next term decreases it.

\subsection{Testing the Model}

Our model predicts that the arrival of additional information forces politicians to adjust their corrupt behavior, increasing pressure for corruption if they believe that they will 
not keep the office for the next term, and decreasing it if they think they are likely to stay for another term. Since we are not able to control for the arrival of new private information, we cannot test this prediction directly. Nevertheless, our data allow for several indirect tests, which probably are not convincing enough when taken separately, but jointly may serve as a reasonable argument in favor of the validity of our theory.

First, note that for the majority of governors in our data sample, we observe what actually happened to them: whether they left office once their term expired or were re-appointed for another term. If we believe that governors accumulate private information throughout their terms and this information is correct, at least on average (i.e. those governors who eventually left office were more likely to think that they will not stay for an extra term, and those who were eventually re-appointed were more likely to think that they will remain in office), we could run our analysis for each group of governors. If our theory is valid, we should observe that those governors who eventually left the office increase pressure for corruption, while those who stayed do not.

To perform such an analysis, we divide governors from our data sample into two groups labeled as Retired and Reassigned. We label a governor as Retired if he is not re-appointed once his current term is over. We label a governor as Reassigned if he is re-appointed for another term once the current term is over, or he requested the president's approval before his term is expired and was then re-appointed ${ }^{6}$ We exclude from the analysis one governor who died while in office, governors who voluntarily resigned since we do not know how far in advance they made this decision, and two governors who were dismissed by the president in the middle of their terms, since they might create an endogeneity problem for our analysis, which we discuss below. There are also several governors in our dataset who were promoted once their terms expired to positions such as federal ministers. Their incentives for corruption while being governors are quite mixed even if they knew they were going to be promoted. On the one hand, if a governor expects to be promoted he knows that he will still be

\footnotetext{
${ }^{6}$ After the abolition of direct gubernatorial elections, governors of several regions asked for the "president's trust": effectively they voluntarily resigned long before the expiration of their current terms, immediately asked for re-appointment for another term, got it, and thus received another four or five years in the office.
} 
in the system in the future and will have opportunities to extract rent, so he does not have much incentive to increase pressure for corruption. On the other hand, knowing that a governor will not be in the region for the next term may give his incentives to extract as much as possible from the region before moving. We do not have enough observations to create separate groups for retired and promoted governors. In the end, we decided to include them in the Retired group and rely on the assumption that the extracting behavior prevails. If the results predicted do not hold - this assumption might be violated.

Kernel densities for Retired and Reassigned governors, available in the data (see Figure 4 in the Appendix for details), suggest that our estimates of the retirement effect may be imprecise in the beginning and around the middle of a governor's term. Overall, our dataset includes 8 Retired and 16 Reassigned governors. The results of the estimation for the Corrupt dependent variable are presented in Table 5. One can see that the variables of interest (Retired and Retired $\times$ Time) are significant at the 5\% level. From the graph of predicted probabilities for the values of Corrupt (Figure 3), it is clear that for the retired governors pressure for corruption increases over time while for the re-appointed it decreases. It is in line with our expectations and predictions of the model: if a governor is likely to leave office once his current term is expired he has stronger incentives to engage in corrupt activities than when he expects to remain in office for another term.

One may argue that the result established may be driven by an endogeneity problem: if a governor engages more deeply in corrupt activities, he is more likely not to be re-appointed. However, we believe this is unlikely to be a driving force for the patterns found. First, as we discussed several times throughout the paper, corrupt behavior has a weak effect on the likelihood of being re-appointed under the Russian political system. Second, when corruption of a regional ruler becomes an issue for the President, there are relatively simple tools for removing him before his term is expired. There were several historical cases when a governor was dismissed and then arrested following accusations of corruption. For example, the governor of Tula region (which is not part 
of the data we analyze in this paper) Vyacheslav Dudka was removed from office by the president in July 2011, just 15 months after his recent re-appointment, arrested and then convicted and jailed for corruption. Recently, in March 2015 the governor of Sakhalin region, which is also not in our data sample, Alexander Khoroshavin was arrested and removed from office following accusations for severe corruption. In our sample, there are two governors who were removed from office (though without accusations in corruption) before their terms expired, the mayor of Moscow Yuri Luzhkov and governor of Novosibirsk region Vasiliy Yurchenko. We exclude these observations from our tests to make sure that this potential endogeneity problem does not drive the results.

For two other tests of our theory, we use information on personal meetings between regional governors and the president of Russia. The president regularly meets governors of Russian regions in different formats: during his visits to regions, on various summits, conferences and other events, and in one-on-one meetings in the Kremlin, his residence and workplace. We believe that if a one-on-one meeting takes place some time close to the term expiration of the governor (we further focus on meetings that took place during the last year before a governor's actual end of term), it resolves or almost resolves governor's uncertainty about his likelihood of remaining in office for another term: during such a meeting the president is likely to fully disclose or strongly signal his intentions regarding re-appointment of the governor. If this is the case, and if our theory is valid, governors should change their corrupt behavior after such meetings. Our data allows us to verify this hypothesis indirectly.

Ideally, we would like to have in our data a set of firms which operated in regions with a governor who then retired, firms which operated in regions with a governor who then stayed for another term, firms that were surveyed before a meeting of the corresponding governor with the president close to the expiration of his term, and those that were surveyed after such a meeting. Unfortunately, we do not have observations of all of these four types, and thus we are limited to indirect and not fully precise, yet informative approaches. 
First, there is one region (Leningradskaya oblast) in our dataset the governor of which was not re-appointed for the next term, had a meeting with the president in the last year of his term, and firms which were surveyed both before ( 84 observations) and after (89 observations) the meeting 7 . According to our theory, firms surveyed after the meeting should perceive higher corruption than the firms surveyed before the meeting. The results of the estimation are presented in column (2) of Table 6. The dummy variable's coefficient for a firm being surveyed after a meeting is weakly significant and positive, which is in line with our expectations.

Second, there are several regions in the dataset whose governors had a meeting with the president in the last year of their terms and then retired once the current terms had expired. In some of these regions firms were surveyed before a meeting (483 firms in 6 regions), while in others they were surveyed after the meeting took place (204 firms in 3 regions). According to the predictions of our model, the latter firms should report higher corruption. Since we do not have a reason to believe that there is a correlation between corruption in a region and dates of the regional firms' survey, a positive significant coefficient of the dummy for a firm being surveyed after a meeting supports our theory. The estimation results are presented in column (1) of Table 6 .

Though each of the three tests of our theory we implement in this section has obvious shortcomings which come from the nature of the data, their results are all fully consistent with each other and with the predictions of our model: higher confidence in not being in office for another term forces incumbents to extract more rent and to put more pressure on local firms for corruption. This is the main finding of the paper.

\section{Conclusion}

In this paper we present evidence that corrupt behavior of politicians follows certain patterns that can be explained by political cycles. Specifically, we find that the corrup-

\footnotetext{
${ }^{7}$ In fact, we have another region, the city of Saint-Petersburg, firms from which were surveyed both before and after the meeting. However, since there are just 4 firms surveyed after the meeting, while there are 91 firms surveyed before the meeting, we cannot perform a reliable analysis in this case.
} 
tion level perceived by firms operating in various regions of Russia increases on average closer to the expected expiration of a regional governor's term of office. This pattern persists after controlling for industry, firm-level, regional and governors' characteristics, both in cross-sectional and pseudo-panel frameworks. We also perform several robustness checks using different estimation approaches and alternative corruption measures and identify a similar trend. We then argue that the established pattern can be explained by the fact that those governors who expect not remain in office for the next term may have incentives to extract more corruption rent while it is available to them. We formalize this idea with a simple theoretical model and then test it using several approaches. Though, due to the nature of the data, the approaches we use have certain limitations, we consistently find a negative relation between the likelihood of a governor to remain in office for the next term and intensity of corruption perception in the corresponding region.

Based on our findings, we believe that there may be a need to strengthen anticorruption control and accountability prior to the expiration of officials' terms, especially for those officials who are less likely to remain in office for the next term. Furthermore, our findings may serve as an indirect argument against appointing systems: as we discussed, a system that assumes the direct election of regional governors by the population may create incentives for incumbent candidates to decrease corruption in order to obtain additional support from voters, which in turn may level the established effect of the risk of not keeping the office for the next term.

\section{References}

Aidt, T. S., Veiga, F. J., and Veiga, L. G. (2011). Election results and opportunistic policies: A new test of the rational political business cycle model. Public Choice, $148(1-2): 21-44$.

Akhmedov, A. and Zhuravskaya, E. (2004). Opportunistic political cycles: Test in a young democracy setting. The Quarterly Journal of Economics, 119(4):1301-1338. 
Brender, A. (2003). The effect of fiscal performance on local government election results in Israel: 1989-1998. Journal of Public Economics, 87(9-10):2187-2205.

Brender, A. and Drazen, A. (2008). How do budget deficits and economic growth affect reelection prospects? Evidence from a large panel of countries. American Economic Review, 98(5):2203-2220.

Collado, M. D. (1997). Estimating dynamic models from time series of independent cross-sections. Journal of Econometrics, 82(1):37-62.

Deaton, A. (1985). Panel data from time series of cross-sections. Journal of Econometrics, 30(1-2):109-126.

Drazen, A. and Eslava, M. (2010). Electoral manipulation via voter-friendly spending: Theory and evidence. Journal of Development Economics, 92(1):39-52.

Guo, G. (2009). China's local political budget cycles. American Journal of Political Science, 53(3):621-632.

Jain, A. K. (2001). Corruption: A review. Journal of Economic Surveys, 15(1):71-121.

Long, J. (1997). Regression Models for Categorical and Limited Dependent Variables. Advanced Quantitative Techniques in the Social Sciences. SAGE Publications.

Martinez, L. (2009). A theory of political cycles. Journal of Economic Theory, 144(3):1166-1186.

McKenzie, D. J. (2004). Asymptotic theory for heterogeneous dynamic pseudo-panels. Journal of Econometrics, 120(2):235-262.

Mironov, M. and Zhuravskaya, E. V. (2014). Corruption in Procurement and the Political Cycle in Tunneling: Evidence from Financial Transactions Data. SSRN Electronic Journal.

Myerson, R. B. (1993). Effectiveness of electoral systems for reducing government corruption: A game-theoretic analysis. Games and Economic Behavior, 5(1):118132. 
Nordhaus, W. D. (1975). The political business cycle. The Review of Economic Studies, 42(2):169.

Persson, T., Roland, G., and Tabellini, G. (1997). Separation of powers and political accountability. The Quarterly Journal of Economics, 112(4):1163-1202.

Persson, T., Tabellini, G., and Trebbi, F. (2003). Electoral rules and corruption. Journal of the European Economic Association, 1(4):958-989.

Petrov, N. and Titkov, A. (2004). Rating of democracy in Russian regions. Technical report, The Moscow Carnegie Center.

Reuter, O. J. and Robertson, G. B. (2012). Subnational appointments in authoritarian regimes: Evidence from Russian gubernatorial appointments. The Journal of Politics, 74(04):1023-1037.

Rogoff, K. and Sibert, A. (1988). Elections and macroeconomic policy cycles. The Review of Economic Studies, 55(1):1-16.

Rogoff, K. S. (1990). Equilibrium political budget cycles. American Economic Review, $80(1): 21-36$

Rose-Ackerman, S. and Soreide, T. (2011). International Handbook on the Economics of Corruption. Edward Elgar Publishing, Cheltenham.

Schneider, C. J. (2009). Fighting with one hand tied behind the back: political budget cycles in the West German states. Public Choice, 142(1-2):125-150.

Shi, M. and Svensson, J. (2006). Political budget cycles: Do they differ across countries and why? Journal of Public Economics, 90(8-9):1367-1389.

Verbeek, M. (2008). Pseudo-panels and repeated cross-sections. In Matyas, L. and Sevestre, P., editors, The Econometrics of Panel Data, volume 46 of Advanced Studies in Theoretical and Applied Econometrics, pages 369-383. Springer Berlin Heidelberg. 


\section{Appendix}

Table 1: Regression Dependent Variable: Corrupt

\begin{tabular}{|c|c|c|c|c|c|c|}
\hline \multirow{2}{*}{ Term completion share } & \multicolumn{2}{|c|}{$\begin{array}{c}(1) \\
\text { OLS }\end{array}$} & \multicolumn{2}{|c|}{$\begin{array}{c}(2) \\
\text { Logit }\end{array}$} & \multicolumn{2}{|c|}{$\begin{array}{c}(3) \\
\text { OLogit }\end{array}$} \\
\hline & $-2.016^{* * *}$ & $(0.633)$ & $-2.862^{* * *}$ & $(0.945)$ & $-2.703^{* * *}$ & $(0.842)$ \\
\hline Term completion share ${ }^{2}$ & $2.037^{* * *}$ & $(0.579)$ & $2.696^{* * *}$ & $(0.910)$ & $2.749^{* * *}$ & $(0.788)$ \\
\hline Foreign ownership & -0.002 & $(0.002)$ & -0.002 & $(0.003)$ & -0.003 & $(0.002)$ \\
\hline Female manager & $-0.153^{* *}$ & $(0.063)$ & $-0.254^{* * *}$ & $(0.086)$ & $-0.210^{* *}$ & $(0.090)$ \\
\hline $\ln$ (Employment) & 0.016 & $(0.017)$ & 0.058 & $(0.035)$ & 0.027 & $(0.022)$ \\
\hline $\ln ($ Firm's age $)$ & $0.052^{*}$ & $(0.028)$ & 0.032 & $(0.038)$ & $0.067^{*}$ & $(0.034)$ \\
\hline 1st term & -0.130 & $(0.094)$ & $-0.285^{* *}$ & $(0.141)$ & $-0.199^{*}$ & $(0.121)$ \\
\hline Ln(Governor's age) & 0.062 & $(0.380)$ & 0.268 & $(0.574)$ & 0.075 & $(0.504)$ \\
\hline Unemployment & -0.023 & $(0.023)$ & -0.028 & $(0.036)$ & -0.029 & $(0.032)$ \\
\hline $\ln ($ State officials per 1000$)$ & -0.351 & $(0.274)$ & $-0.879^{* *}$ & $(0.395)$ & -0.453 & $(0.365)$ \\
\hline $\ln ($ Region population $)$ & 0.128 & $(0.096)$ & 0.064 & $(0.143)$ & 0.153 & $(0.125)$ \\
\hline $\ln ($ Real GRP per capita) & -0.089 & $(0.138)$ & -0.098 & $(0.221)$ & -0.109 & $(0.195)$ \\
\hline City size & 0.025 & $(0.039)$ & 0.069 & $(0.065)$ & 0.028 & $(0.052)$ \\
\hline Carnegie 2000-2004 & -0.022 & $(0.100)$ & -0.141 & $(0.132)$ & -0.046 & $(0.131)$ \\
\hline Elections 2007, UR's share & $0.024^{*}$ & $(0.013)$ & 0.018 & $(0.019)$ & $0.031^{*}$ & $(0.017)$ \\
\hline Elections 2007, turnout & $-0.024^{* *}$ & $(0.011)$ & -0.021 & $(0.016)$ & $-0.031^{* *}$ & $(0.014)$ \\
\hline Constant & 2.758 & $(2.754)$ & 4.426 & $(4.100)$ & & \\
\hline Year $=2008$ & -0.176 & $(0.140)$ & -0.047 & $(0.232)$ & -0.247 & $(0.182)$ \\
\hline Year $=2011$ & $-0.834^{* * *}$ & $(0.125)$ & $-1.190^{* * *}$ & $(0.166)$ & $-1.087^{* * *}$ & $(0.160)$ \\
\hline Year $=2012$ & $-0.845^{* * *}$ & $(0.134)$ & $-1.149^{* * *}$ & $(0.189)$ & $-1.099^{* * *}$ & $(0.175)$ \\
\hline cut1 & & & & & -2.164 & $(3.815)$ \\
\hline cut2 & & & & & -1.586 & $(3.816)$ \\
\hline cut3 & & & & & -0.851 & $(3.808)$ \\
\hline cut4 & & & & & 0.343 & $(3.823)$ \\
\hline Industry fixed effects & Yes & & Yes & & Yes & \\
\hline Log likelihood & -8798 & & -3115 & & -7313 & \\
\hline Clusters (Regions) & 37 & & 37 & & 37 & \\
\hline McFadden's Adjusted R ${ }^{2}$ & 0.022 & & 0.053 & & 0.026 & \\
\hline Pseudo $\mathrm{R}^{2}$ & & & 0.064 & & 0.031 & \\
\hline Observations & 4992 & & 4992 & & 4992 & \\
\hline
\end{tabular}

Standard errors in parentheses. Raw coefficients

Source: Own calculations based on the EBRD and World Bank BEEPS survey

${ }^{*} p<0.10,{ }^{* *} p<0.05,{ }^{* * *} p<0.01$ 
Table 2: Regression Dependent Variable: Corrupt

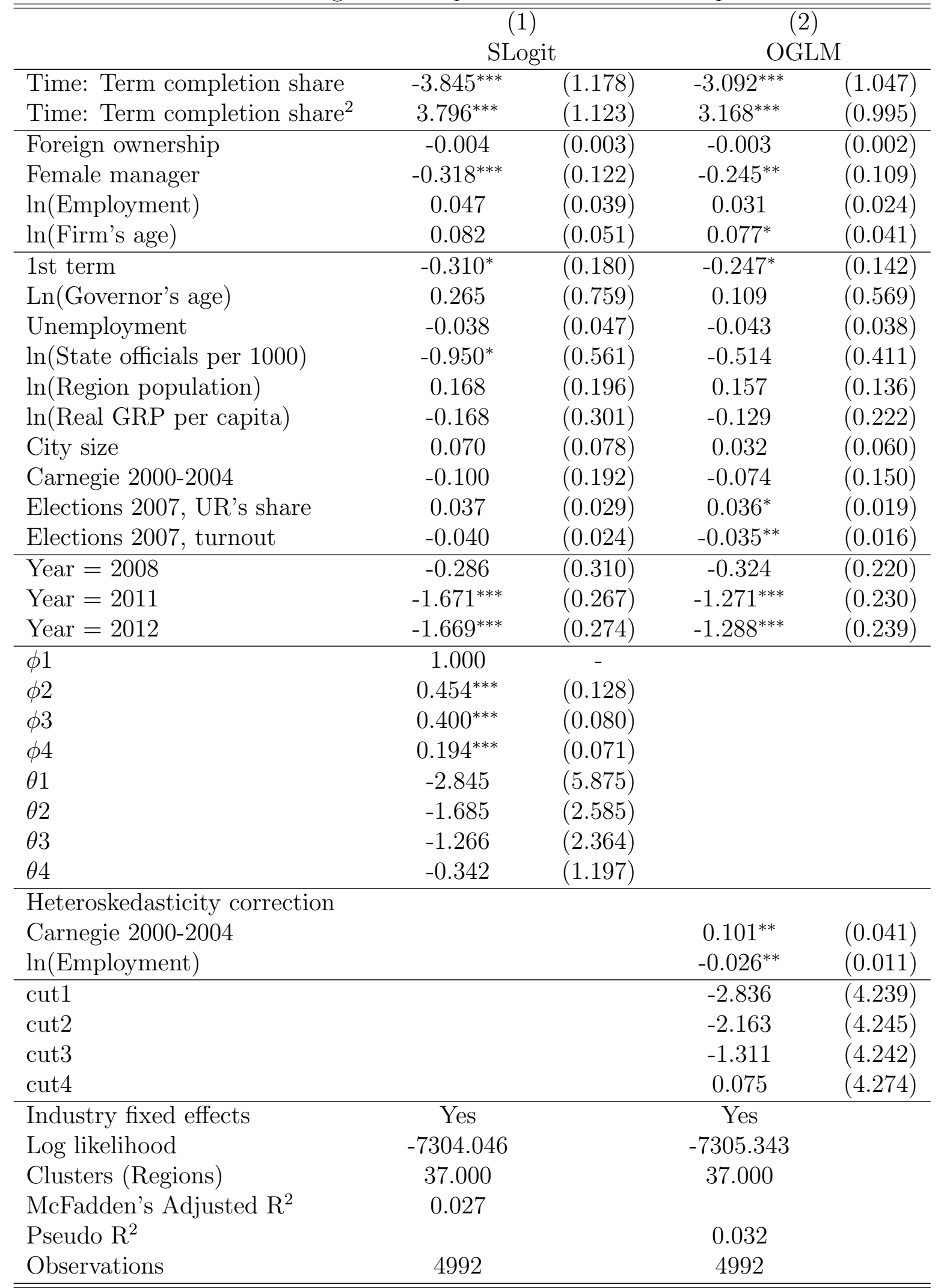

Standard errors in parentheses. Raw coefficients

Source: Own calculations based on the EBRD and World Bank BEEPS survey

${ }^{*} p<0.10,{ }^{* *} p<0.05,{ }^{* * *} p<0.01$ 
Table 3: Regression Dependent Variables: CorSale (Share of Annual Sales Paid As Bribes)

\begin{tabular}{|c|c|c|c|c|c|c|c|c|}
\hline \multirow{4}{*}{$\begin{array}{l}\text { Time: Term completion share } \\
\text { Time: Term completion share }\end{array}$} & \multirow{2}{*}{\multicolumn{2}{|c|}{$\begin{array}{c}(1) \\
\text { OLS(CorSale })\end{array}$}} & \multirow{2}{*}{\multicolumn{2}{|c|}{$\begin{array}{c}(2) \\
\text { Logit(CorSale) }\end{array}$}} & \multicolumn{4}{|c|}{$\begin{array}{ll} & (3)\end{array}$} \\
\hline & & & & & \multicolumn{2}{|c|}{ Two-part: Logit(CorSale) } & \multicolumn{2}{|c|}{ Two-part: GLM(CorSale) } \\
\hline & $-0.035^{*}$ & $(0.018)$ & $-4.806^{* * *}$ & $(1.282)$ & $-4.806^{* * *}$ & $(1.282)$ & 0.093 & $(0.079)$ \\
\hline & $0.043^{* *}$ & $(0.017)$ & $4.976^{* * *}$ & $(1.261)$ & $4.976^{* * *}$ & $(1.261)$ & -0.066 & $(0.077)$ \\
\hline Foreign ownership & $-0.000^{* * *}$ & $(0.000)$ & 0.001 & $(0.005)$ & 0.001 & $(0.005)$ & $-0.000^{* * *}$ & $(0.000)$ \\
\hline Female manager & $-0.003^{*}$ & $(0.002)$ & $-0.343^{* *}$ & $(0.149)$ & $-0.343^{* *}$ & $(0.149)$ & -0.005 & $(0.010)$ \\
\hline $\ln ($ Employment $)$ & -0.001 & $(0.001)$ & 0.043 & $(0.048)$ & 0.043 & $(0.048)$ & $-0.006^{* *}$ & $(0.003)$ \\
\hline $\ln ($ Firm's age $)$ & 0.001 & $(0.001)$ & 0.043 & $(0.090)$ & 0.043 & $(0.090)$ & 0.005 & $(0.005)$ \\
\hline 1st term & -0.002 & $(0.002)$ & $-0.398^{*}$ & $(0.215)$ & $-0.398^{*}$ & $(0.215)$ & 0.000 & $(0.011)$ \\
\hline Ln(Governor's age) & $-0.030^{* * *}$ & $(0.010)$ & -0.927 & $(0.745)$ & -0.927 & $(0.745)$ & $-0.094^{* *}$ & $(0.039)$ \\
\hline Unemployment & $0.001^{*}$ & $(0.001)$ & $0.115^{*}$ & $(0.064)$ & $0.115^{*}$ & $(0.064)$ & 0.004 & $(0.004)$ \\
\hline $\ln ($ State officials per 1000$)$ & $-0.015^{*}$ & $(0.008)$ & -1.250 & $(0.920)$ & -1.250 & $(0.920)$ & -0.024 & $(0.038)$ \\
\hline $\ln ($ Region population $)$ & 0.000 & $(0.002)$ & 0.242 & $(0.223)$ & 0.242 & $(0.223)$ & -0.001 & $(0.009)$ \\
\hline $\ln ($ Real GRP per capita) & 0.001 & $(0.003)$ & -0.065 & $(0.367)$ & -0.065 & $(0.367)$ & 0.000 & $(0.013)$ \\
\hline City size & -0.001 & $(0.001)$ & 0.067 & $(0.100)$ & 0.067 & $(0.100)$ & -0.001 & $(0.006)$ \\
\hline Carnegie 2000-2004 & -0.001 & $(0.002)$ & $-0.327^{* *}$ & $(0.157)$ & $-0.327^{* *}$ & $(0.157)$ & $0.016^{*}$ & $(0.009)$ \\
\hline Elections 2007, UR's share & $0.001^{* *}$ & $(0.000)$ & $0.061^{* *}$ & $(0.029)$ & $0.061^{* *}$ & $(0.029)$ & -0.001 & $(0.001)$ \\
\hline Elections 2007, turnout & -0.000 & $(0.000)$ & -0.017 & $(0.024)$ & -0.017 & $(0.024)$ & -0.000 & $(0.001)$ \\
\hline Constant & $0.160^{* *}$ & $(0.069)$ & 2.944 & $(7.910)$ & 2.944 & $(7.910)$ & $0.528^{*}$ & $(0.279)$ \\
\hline Year $=2008$ & $0.035^{* * *}$ & $(0.010)$ & $4.396^{* * *}$ & $(0.654)$ & $4.396^{* * *}$ & $(0.654)$ & 0.002 & $(0.015)$ \\
\hline Year $=2011$ & $-0.023^{* * *}$ & $(0.007)$ & $-2.344^{* * *}$ & $(0.383)$ & $-2.344^{* * *}$ & $(0.383)$ & 0.017 & $(0.014)$ \\
\hline Year $=2012$ & $-0.021^{* * *}$ & $(0.007)$ & $-2.056^{* * *}$ & $(0.420)$ & $-2.056^{* * *}$ & $(0.420)$ & 0.021 & $(0.022)$ \\
\hline Industry fixed effects & Yes & & Yes & & & & & \\
\hline Log likelihood & 6091 & & -1146 & & & & & \\
\hline Clusters (Regions) & 37 & & 37 & & & & & \\
\hline Adjusted $\mathrm{R}^{2}$ & 0.059 & & & & & & & \\
\hline Pseudo $\mathrm{R}^{2}$ & & & 0.217 & & & & & \\
\hline Observations & 3508 & & 3508 & & & & & \\
\hline
\end{tabular}

Standard errors in parentheses. Raw coefficients

Source: Own calculations based on the EBRD and World Bank BEEPS survey

${ }^{*} p<0.10,{ }^{* *} p<0.05,{ }^{* * *} p<0.01$ 

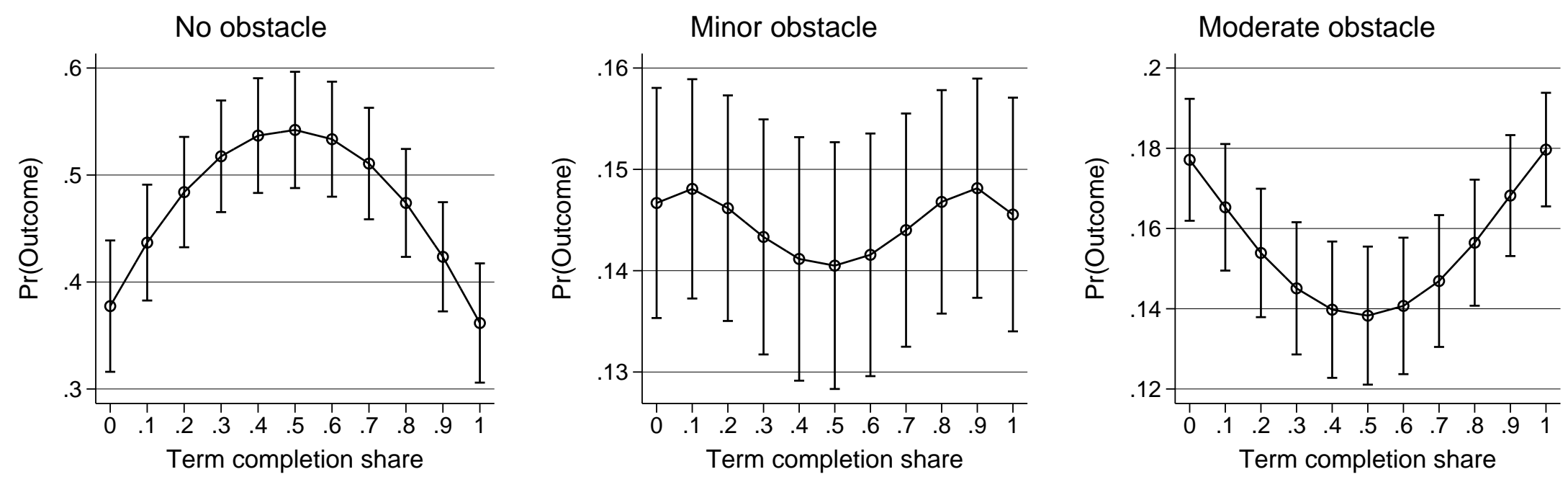

$\stackrel{c o s}{i j}$
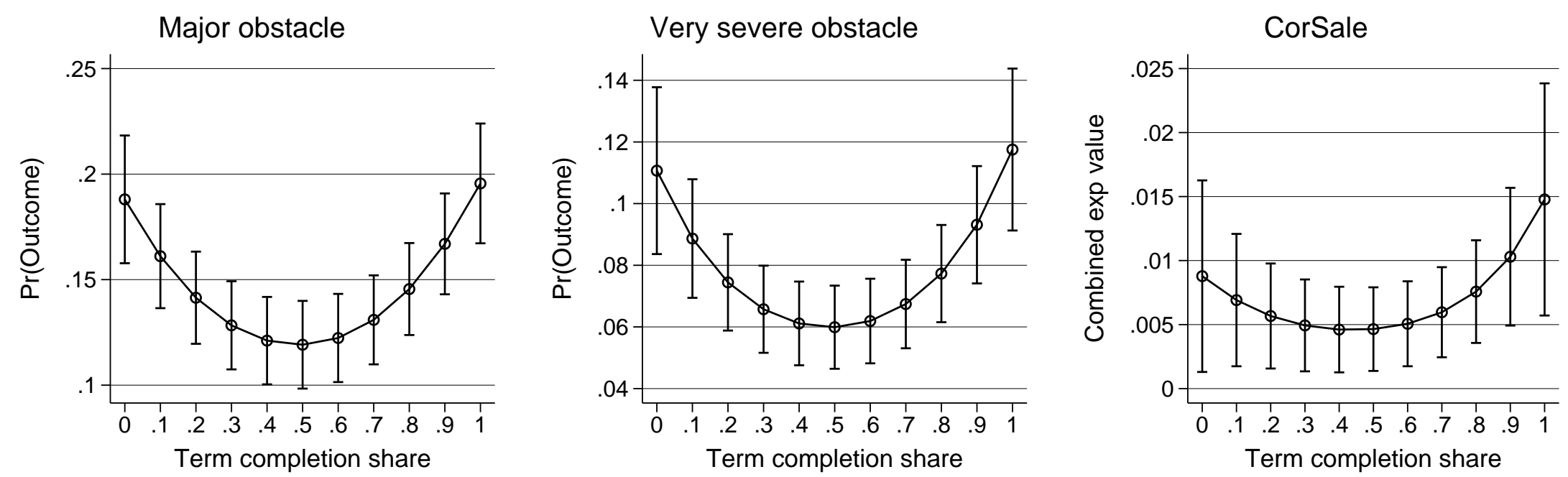

Figure 1: Predicted probabilities of Corrupt outcomes by Time. 
Table 4: Regression Dependent Variable: Corrupt (Group Mean)

\begin{tabular}{lcccc}
\hline \hline & \multicolumn{2}{c}{$(1)$} & \multicolumn{2}{c}{$(2)$} \\
& \multicolumn{2}{c}{ RE (Corrupt) } & \multicolumn{2}{c}{ FE (Corrupt) } \\
\hline Term completion share & $-2.988^{* * *}$ & $(1.022)$ & $-3.580^{* * *}$ & $(1.117)$ \\
Term completion share & $2.943^{* * *}$ & $(0.915)$ & $3.309^{* * *}$ & $(0.914)$ \\
\hline Foreign ownership & -0.017 & $(0.016)$ & -0.023 & $(0.015)$ \\
Female manager & -0.385 & $(0.532)$ & -0.864 & $(0.827)$ \\
$\ln ($ Employment) & -0.005 & $(0.095)$ & -0.001 & $(0.095)$ \\
$\ln ($ Firm's age) & 0.258 & $(0.248)$ & 0.083 & $(0.273)$ \\
1st term & 0.019 & $(0.108)$ & 0.217 & $(0.194)$ \\
Ln(Governor's age) & -0.361 & $(0.341)$ & -1.381 & $(1.445)$ \\
Unemployment & -0.015 & $(0.031)$ & -0.155 & $(0.110)$ \\
$\ln ($ State officials per 1000) & -0.229 & $(0.546)$ & 0.399 & $(1.498)$ \\
$\ln ($ Region population) & 0.116 & $(0.179)$ & 6.703 & $(5.378)$ \\
$\ln ($ Real GRP per capita) & 0.068 & $(0.184)$ & 0.824 & $(1.188)$ \\
City size & 0.040 & $(0.101)$ & -0.166 & $(0.189)$ \\
\hline Year $=2008$ & $-0.305^{*}$ & $(0.180)$ & -0.359 & $(0.573)$ \\
Year $=2011$ & $-0.923^{* * *}$ & $(0.168)$ & $-1.447^{* * *}$ & $(0.480)$ \\
Year $=2012$ & $-0.957^{* * *}$ & $(0.151)$ & $-1.770^{* *}$ & $(0.732)$ \\
\hline Groups (Regions) & 37 & & 37 & \\
Chi squared & 447 & & & \\
Observations & 107 & & 107 & \\
\hline \hline
\end{tabular}

Standard errors in parentheses

Raw coefficients

Source: Own calculations based on the EBRD and World Bank BEEPS survey

${ }^{*} p<0.10,{ }^{* *} p<0.05,{ }^{* * *} p<0.01$ 
Fixed Effects

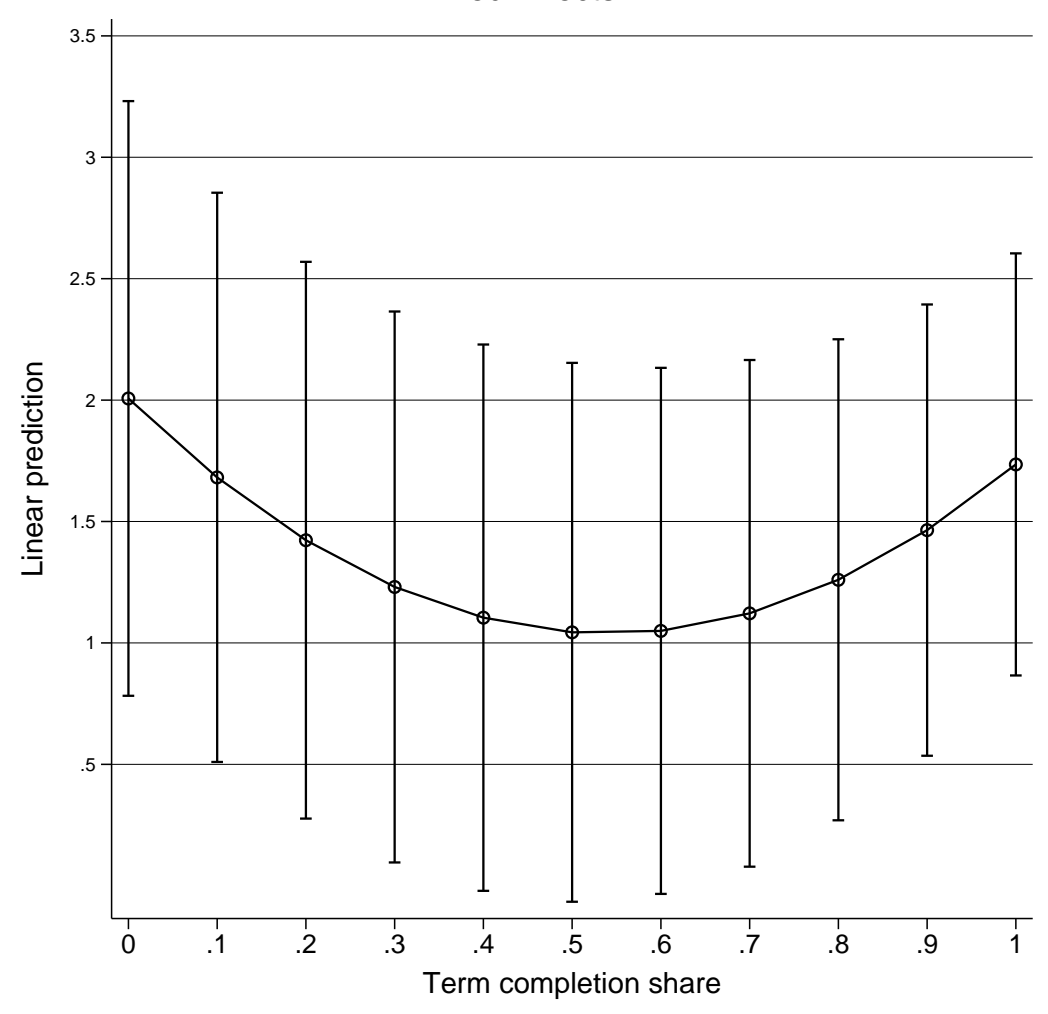

Random Effects

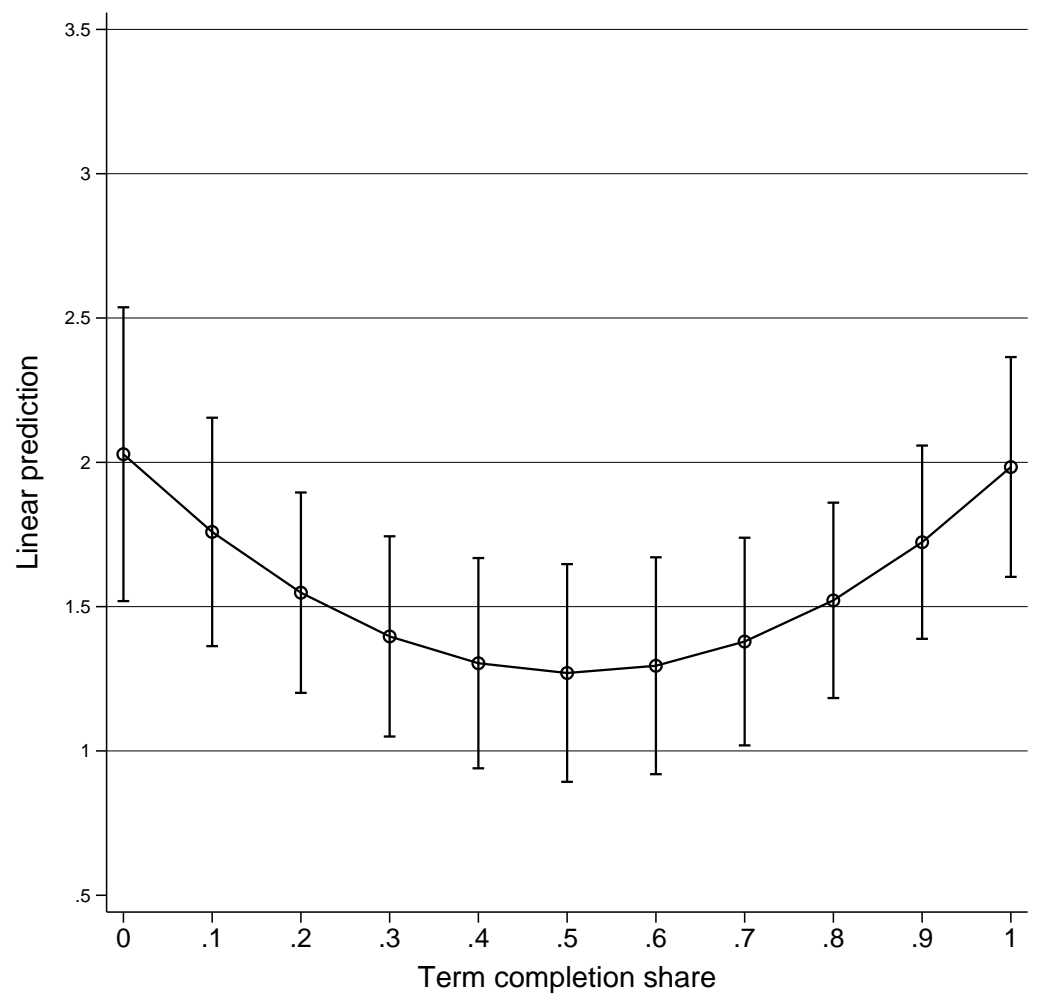

Figure 2: Linear predictions of region-average corruption levels after FE and RE regression. 
Table 5: Regression: Effect of Governor's Retirement

\begin{tabular}{|c|c|c|}
\hline & \multicolumn{2}{|c|}{$\begin{array}{c}(1) \\
\text { OGLM(Corrupt) }\end{array}$} \\
\hline Time: Term completion share & $-3.142^{* * *}$ & $(0.806)$ \\
\hline Time: Term completion share ${ }^{2}$ & $2.284^{* * *}$ & $(0.855)$ \\
\hline Retired & $-1.768^{*}$ & $(0.915)$ \\
\hline Retired $\times$ Time: Term completion share & $5.869^{* *}$ & $(2.821)$ \\
\hline Retired $\times$ Time: Term completion share ${ }^{2}$ & $-4.149^{*}$ & $(2.261)$ \\
\hline 1st term & -0.052 & $(0.154)$ \\
\hline Foreign ownership & $-0.006^{* * *}$ & $(0.002)$ \\
\hline Female manager & -0.149 & $(0.117)$ \\
\hline $\ln ($ Employment $)$ & -0.000 & $(0.035)$ \\
\hline $\ln ($ Firm's age $)$ & 0.054 & $(0.061)$ \\
\hline Ln(Governor's age) & 0.659 & $(0.798)$ \\
\hline Unemployment & -0.048 & $(0.047)$ \\
\hline $\ln ($ State officials per 1000$)$ & 1.316 & $(0.904)$ \\
\hline $\ln ($ Region population $)$ & $0.489^{* *}$ & $(0.237)$ \\
\hline $\ln ($ Real GRP per capita) & $-0.447^{* *}$ & $(0.206)$ \\
\hline City size & $-0.266^{* *}$ & $(0.120)$ \\
\hline Carnegie 2000-2004 & 0.147 & $(0.090)$ \\
\hline Elections 2007, UR's share & 0.004 & $(0.025)$ \\
\hline Elections 2007, turnout & -0.027 & $(0.020)$ \\
\hline Year $=2008$ & $-0.724^{*}$ & $(0.371)$ \\
\hline Year $=2011$ & $-1.140^{* *}$ & $(0.459)$ \\
\hline Year $=2012$ & $-1.285^{* * *}$ & $(0.475)$ \\
\hline \multicolumn{3}{|l|}{ Heteroskedasticity correction } \\
\hline Carnegie 2000-2004 & -0.011 & $(0.066)$ \\
\hline $\ln ($ Employment $)$ & -0.016 & $(0.019)$ \\
\hline cut1 & 3.809 & $(8.303)$ \\
\hline cut2 & 4.368 & $(8.324)$ \\
\hline cut3 & 5.079 & $(8.336)$ \\
\hline cut4 & 6.196 & $(8.391)$ \\
\hline Industry fixed effects & Yes & \\
\hline Log likelihood & -2867 & \\
\hline Clusters (Regions) & 22 & \\
\hline Pseudo $R^{2}$ & 0.049 & \\
\hline Observations & 1980 & \\
\hline
\end{tabular}

Standard errors in parentheses

Raw coefficients

Source: own calculations based on the EBRD and World Bank BEEPS survey

${ }^{*} p<0.10,{ }^{* *} p<0.05,{ }^{* * *} p<0.01$ 

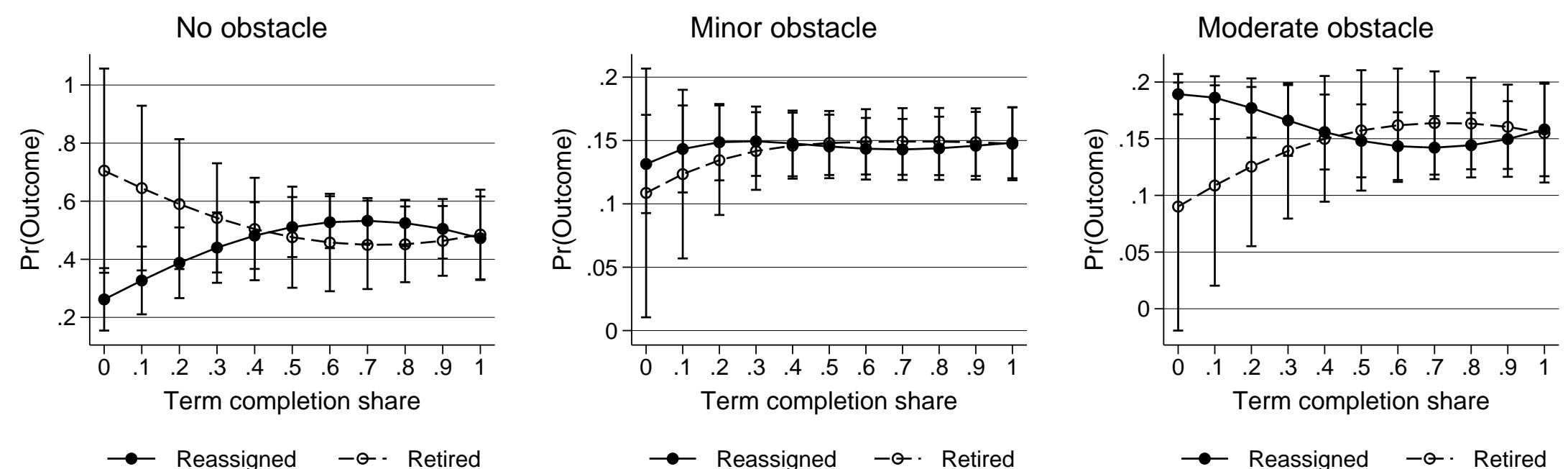

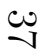
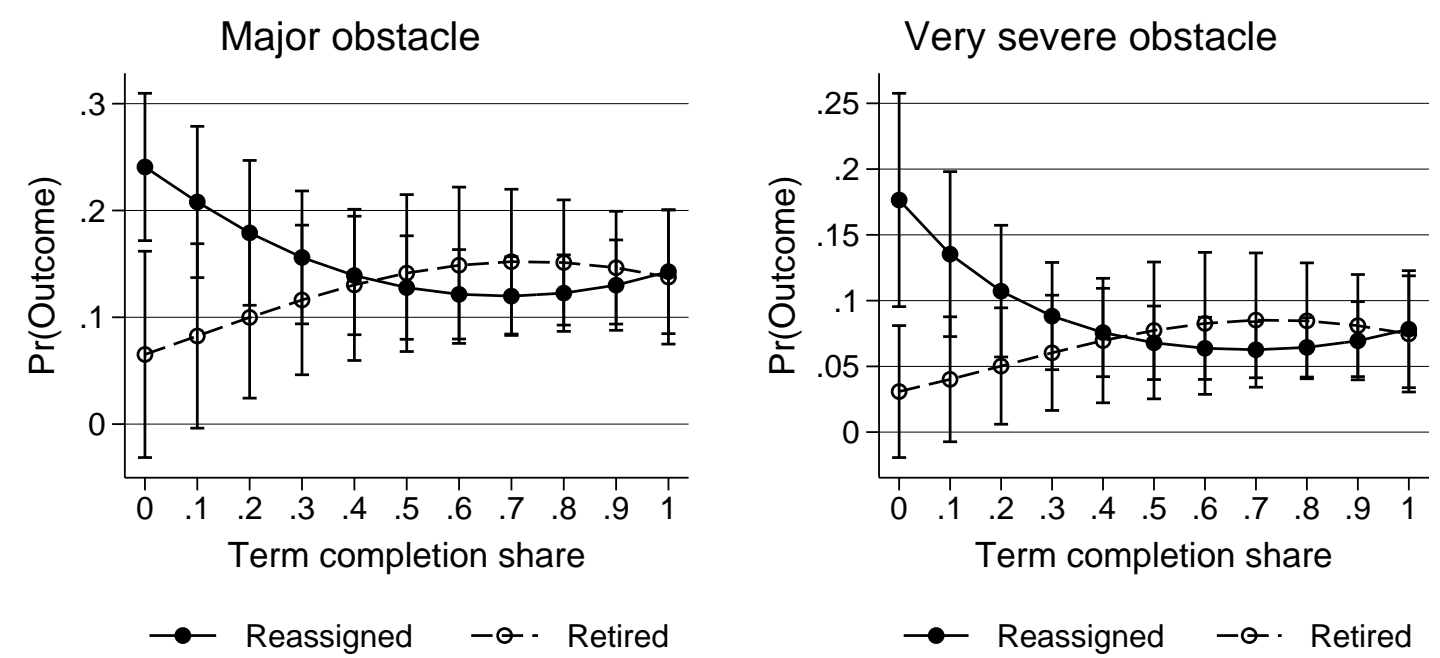

Figure 3: Predicted probabilities of Corrupt outcomes by Time for Retired and Reassigned governors. 
Table 6: Regression: Effect of Meeting With The President

\begin{tabular}{lcccc}
\hline \hline & \multicolumn{2}{c}{$(1)$} & \multicolumn{2}{c}{$(2)$} \\
& \multicolumn{2}{c}{ OLogit(Corrupt) } & \multicolumn{2}{c}{ OLogit(Corrupt) } \\
\hline Meeting president & $0.772^{*}$ & $(0.435)$ & $0.924^{* *}$ & $(0.469)$ \\
1st term & -10.168 & $(7.265)$ & - & - \\
Foreign ownership & 0.004 & $(0.006)$ & 0.003 & $(0.009)$ \\
Female manager & $-0.776^{* * *}$ & $(0.235)$ & $-1.537^{* * *}$ & $(0.453)$ \\
ln(Employment) & -0.042 & $(0.063)$ & -0.183 & $(0.145)$ \\
ln(Firm's age) & -0.077 & $(0.105)$ & -0.010 & $(0.238)$ \\
\hline Ln(Governor's age) & -17.582 & $(17.050)$ & 5.113 & $(70.279)$ \\
Unemployment & 0.245 & $(0.344)$ & 0.186 & $(0.985)$ \\
ln(State officials per 1000) & -16.247 & $(10.424)$ & -9.126 & $(44.515)$ \\
ln(Region population) & $-31.162^{*}$ & $(18.698)$ & - & - \\
ln(Real GRP per capita) & 4.733 & $(3.270)$ & - & - \\
City size & 0.151 & $(0.141)$ & 0.194 & $(0.321)$ \\
Carnegie 2000-2004 & -10.395 & $(7.300)$ & - & - \\
Elections 2007, UR's share & $-3.010^{*}$ & $(1.746)$ & - & - \\
Elections 2007, turnout & $2.195^{*}$ & $(1.280)$ & - & - \\
\hline Year = 2008 & 1.020 & $(2.072)$ & - & - \\
Year = 2011 & -0.407 & $(1.332)$ & - & - \\
Year = 2012 & -0.691 & $(2.096)$ & - & - \\
\hline cut1 & -606.523 & $(419.713)$ & -7.727 & $(168.986)$ \\
cut2 & -605.643 & $(419.703)$ & -6.524 & $(169.008)$ \\
cut3 & -604.827 & $(419.701)$ & -5.641 & $(168.990)$ \\
cut4 & -603.477 & $(419.694)$ & -4.386 & $(168.977)$ \\
\hline Industry fixed effects & Yes & & Yes & \\
Log likelihood & -1007 & & -252 & \\
McFadden's Adjusted R ${ }^{2}$ & 0.030 & & -0.028 & \\
Pseudo R $R^{2}$ & 0.065 & & 0.051 & \\
Observations & 688 & & & \\
\hline \hline & & & & \\
\hline
\end{tabular}

Standard errors in parentheses

Raw coefficients

Source: own calculations based on the EBRD and World Bank BEEPS survey

${ }^{*} p<0.10,{ }^{* *} p<0.05,{ }^{* * *} p<0.01$ 
Table 7: Summary Statistics: Time by Regions

\begin{tabular}{|c|c|c|c|c|c|c|c|}
\hline \multicolumn{8}{|c|}{ (1) } \\
\hline & count & $\min$ & $\max$ & $\mathrm{p} 50$ & mean & sd & wave \\
\hline Belgorod Region & 117 & 0.833 & 0.900 & 0.883 & 0.871 & 0.017 & $\mathrm{~V}$ \\
\hline Chelyabinsk Region & 90 & 0.267 & 0.750 & 0.333 & 0.392 & 0.164 & IV, $\mathrm{V}$ \\
\hline Irkutsk Region & 118 & 0.469 & 0.531 & 0.516 & 0.507 & 0.016 & $\mathrm{~V}$ \\
\hline Kaliningrad Region & 117 & 0.183 & 0.283 & 0.217 & 0.229 & 0.033 & $\mathrm{~V}$ \\
\hline Kaluga Region & 129 & 0.233 & 0.847 & 0.367 & 0.450 & 0.205 & IV,V \\
\hline Kemerovo Region & 115 & 0.267 & 0.433 & 0.367 & 0.362 & 0.044 & $\mathrm{~V}$ \\
\hline Khabarosvk Territory & 114 & 0.583 & 0.708 & 0.646 & 0.645 & 0.038 & $\mathrm{~V}$ \\
\hline Kirov Region & 95 & 0.517 & 0.633 & 0.617 & 0.598 & 0.037 & $\mathrm{~V}$ \\
\hline Krasnodar Territory & 109 & 0 & 0.983 & 0.883 & 0.676 & 0.355 & IV,V \\
\hline Krasnoyarsk Territory & 119 & 0.197 & 0.443 & 0.361 & 0.347 & 0.056 & IV,V \\
\hline Kursk Region & 101 & 0.295 & 0.800 & 0.361 & 0.443 & 0.178 & IV,V \\
\hline Leningrad Region & 166 & 0.250 & 0.950 & 0.842 & 0.677 & 0.277 & IV,V \\
\hline Lipetsk Region & 107 & 0.267 & 0.400 & 0.367 & 0.342 & 0.040 & $\mathrm{~V}$ \\
\hline Moscow City & 352 & 0.125 & 0.542 & 0.365 & 0.357 & 0.110 & IV, $\mathrm{V}$ \\
\hline Moscow Region & 251 & 0.133 & 0.983 & 0.367 & 0.594 & 0.302 & IV,V \\
\hline Murmansk Region & 105 & 0 & 0.617 & 0.517 & 0.438 & 0.218 & $\mathrm{~V}$ \\
\hline Nizhni Novgorod Region & 108 & 0.200 & 0.817 & 0.267 & 0.399 & 0.219 & IV,V \\
\hline Novosibirsk Region & 160 & 0.117 & 0.333 & 0.242 & 0.242 & 0.040 & IV,V \\
\hline Omsk Region & 116 & 0.850 & 0.967 & 0.917 & 0.908 & 0.035 & $\mathrm{~V}$ \\
\hline Perm Territory & 156 & 0.133 & 0.750 & 0.167 & 0.263 & 0.193 & IV, V \\
\hline Primorsky Territory & 194 & 0.317 & 0.833 & 0.383 & 0.556 & 0.209 & IV,V \\
\hline Republic of Bashkortostan & 158 & 0.217 & 0.583 & 0.300 & 0.332 & 0.114 & IV,V \\
\hline Republic of Mordovia & 119 & 0.167 & 0.267 & 0.233 & 0.223 & 0.034 & $\mathrm{~V}$ \\
\hline Republic of Sakha (Yakutia) & 89 & 0.267 & 0.383 & 0.283 & 0.294 & 0.029 & V \\
\hline Republic of Tatarstan & 115 & 0.283 & 0.367 & 0.317 & 0.317 & 0.020 & $\mathrm{~V}$ \\
\hline Rostov Region & 166 & 0.233 & 0.733 & 0.300 & 0.394 & 0.188 & IV, $\mathrm{V}$ \\
\hline Saint Petersburg & 187 & 0 & 0.933 & 0.333 & 0.252 & 0.208 & IV,V \\
\hline Samara Region & 151 & 0.233 & 0.867 & 0.800 & 0.703 & 0.220 & IV,V \\
\hline Smolensk Region & 63 & 0.167 & 0.867 & 0.767 & 0.735 & 0.165 & IV,V \\
\hline Stavropol Territory & 116 & 0.650 & 0.717 & 0.683 & 0.687 & 0.021 & $\mathrm{~V}$ \\
\hline Sverdlovsk Region & 143 & 0.367 & 0.792 & 0.450 & 0.484 & 0.135 & IV, $\mathrm{V}$ \\
\hline Tomsk Region & 121 & 0 & 1 & 0.933 & 0.855 & 0.287 & $\mathrm{~V}$ \\
\hline Tver Region & 141 & 0.0328 & 0.433 & 0.131 & 0.141 & 0.093 & IV, $\mathrm{V}$ \\
\hline Ulyanovsk Region & 112 & 0.100 & 0.217 & 0.175 & 0.162 & 0.041 & $\mathrm{~V}$ \\
\hline Volgograd Region & 107 & 0 & 0.393 & 0.0492 & 0.150 & 0.159 & $\mathrm{~V}$ \\
\hline Voronezh Region & 150 & 0.0164 & 1 & 0.525 & 0.603 & 0.202 & IV,V \\
\hline Yaroslavl Region & 115 & 0.846 & 0.981 & 0.904 & 0.910 & 0.038 & $\mathrm{~V}$ \\
\hline Total & 4992 & 0 & 1 & 0.375 & 0.466 & 0.268 & \\
\hline
\end{tabular}


Table 8: Summary Statistics: Main Variables and Controls

\begin{tabular}{lcccccc}
\hline \hline & $(1)$ & & & & & \\
& count & $\min$ & $\max$ & $\mathrm{p} 50$ & $\operatorname{mean}$ & $\mathrm{sd}$ \\
\hline Corrupt: Obstacle to current operations & 4992 & 0 & 4 & 1 & 1.548 & 1.477 \\
CorSale: Share of annual sales paid & 3339 & 0 & 0.600 & 0 & 0.012 & 0.0450 \\
Time: Term completion share & 4992 & 0 & 1 & 0.375 & 0.466 & 0.268 \\
\hline \hline
\end{tabular}

Table 9: Summary Statistics: Controls

\begin{tabular}{lcccccc}
\hline \hline & $(1)$ & & & & & \\
& count & $\min$ & $\max$ & $\mathrm{p} 50$ & mean & sd \\
\hline Foreign ownership & 4992 & 0 & 100 & 0 & 2.437 & 14.261 \\
Female manager & 4992 & 0 & 1 & 0 & 0.206 & 0.405 \\
$\ln$ (Employment) & 4992 & 1.609 & 11.51 & 2.996 & 3.236 & 1.341 \\
$\ln$ (Firm's age) & 4992 & 0 & 5.159 & 2.197 & 2.188 & 0.785 \\
\hline 1st term & 4992 & 0 & 1 & 1 & 0.517 & 0.500 \\
Ln(Governor's age) & 4992 & 3.584 & 4.317 & 4.025 & 4.022 & 0.153 \\
Unemployment & 4992 & 0.800 & 10 & 6 & 5.895 & 2.079 \\
$\ln$ (State officials per 1000) & 4992 & 2.398 & 3.524 & 3.105 & 3.105 & 0.246 \\
$\ln$ (Region population) & 4992 & 13.57 & 16.29 & 14.78 & 14.728 & 0.717 \\
$\ln$ (Real GRP per capita) & 4992 & 11.46 & 14.01 & 12.53 & 12.583 & 0.459 \\
City size & 4992 & 1 & 5 & 3 & 2.848 & 0.830 \\
Carnegie 2000-2004 & 4992 & 1 & 3 & 2 & 2.319 & 0.576 \\
Elections 2007, UR's share & 4992 & 50.33 & 93.41 & 60.26 & 61.738 & 8.670 \\
Elections 2007, turnout & 4992 & 51.46 & 94.49 & 59.54 & 62.606 & 9.998 \\
\hline \hline
\end{tabular}

Table 10: Summary Statistics: Years

\begin{tabular}{lccc}
\hline \hline & $(1)$ & & \\
& frequency & percentage & cum. percentage \\
\hline 2008 & 599 & 12.00 & 12.00 \\
2009 & 506 & 10.14 & 22.14 \\
2011 & 2689 & 53.87 & 76.00 \\
2012 & 1198 & 24.00 & 100.00 \\
\hline Total & 4992 & 100.00 & \\
\hline \hline
\end{tabular}


Full sample

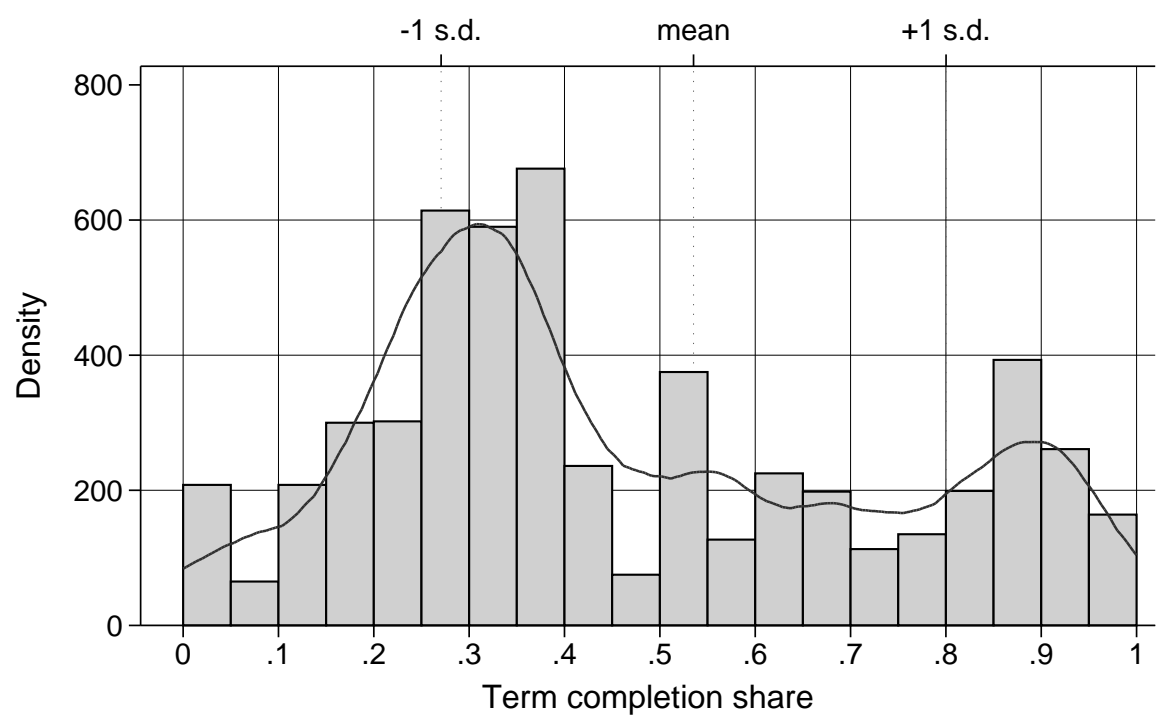

Retired

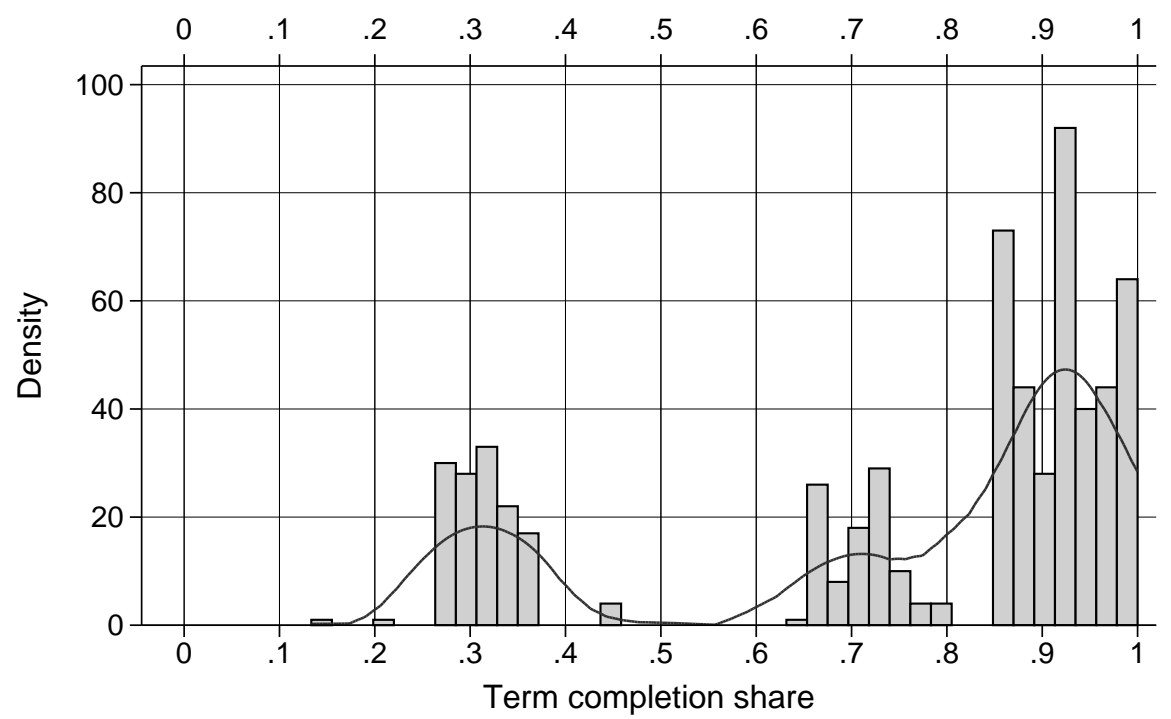

Reassigned

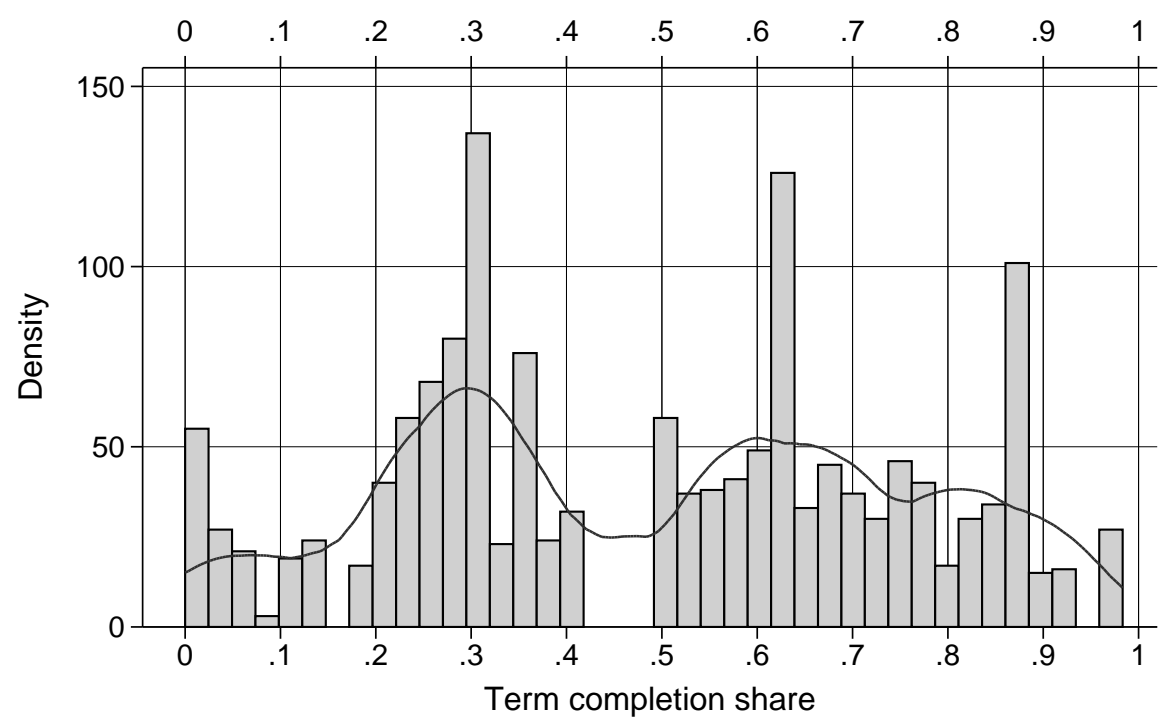

Figure 4: Kernel densities of term completion share; overall and by Retired and Reassigned statuses. 


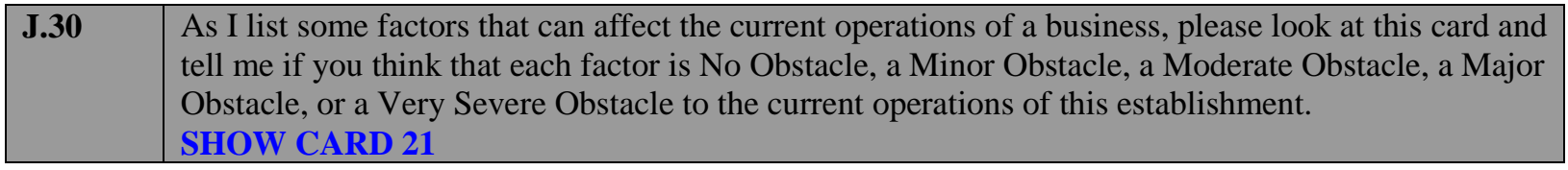

\begin{tabular}{|c|c|c|c|c|c|c|c|}
\hline ROTATE OPTIONS & $\begin{array}{c}\text { No } \\
\text { obstacle }\end{array}$ & $\begin{array}{c}\text { Minor } \\
\text { obstacle }\end{array}$ & $\begin{array}{c}\text { Moderate } \\
\text { obstacle }\end{array}$ & $\begin{array}{c}\text { Major } \\
\text { obstacle }\end{array}$ & $\begin{array}{c}\text { Very } \\
\text { Severe } \\
\text { Obstacle }\end{array}$ & $\begin{array}{c}\text { Do } \\
\text { Not } \\
\text { Know } \\
\text { (spon } \\
\text { taneo } \\
\text { us) } \\
\end{array}$ & $\begin{array}{c}\text { Does } \\
\text { Not } \\
\text { Apply } \\
\text { (spont } \\
\text { aneous } \\
\text { ) } \\
\end{array}$ \\
\hline Tax rates & 0 & 1 & 2 & 3 & 4 & -9 & -7 \\
\hline Tax administration $\quad$ j30b & 0 & 1 & 2 & 3 & 4 & -9 & -7 \\
\hline Business licensing and permits j30c & 0 & 1 & 2 & 3 & 4 & -9 & -7 \\
\hline $\begin{array}{ll}\text { Political instability } & \text { j30e } \\
\end{array}$ & 0 & 1 & 2 & 3 & 4 & -9 & -7 \\
\hline Corruption & 0 & 1 & 2 & 3 & 4 & -9 & -7 \\
\hline Courts & 0 & 1 & 2 & 3 & 4 & -9 & -7 \\
\hline
\end{tabular}

\begin{tabular}{|l|l|}
\hline J.7 & It is said that establishments are sometimes required to make gifts or informal payments to public \\
\hline
\end{tabular} officials to "get things done" with regard to customs, taxes, licenses, regulations, services etc. On average, what percent of total annual sales, or estimated total annual value, do establishments like this one pay in informal payments or gifts to public officials for this purpose?

\begin{tabular}{|l|r|}
\cline { 2 - 2 } \multicolumn{1}{c|}{} & \multicolumn{1}{c|}{ Percent } \\
\hline \hline Percent of total annual sales paid as informal payment & j7a \% \\
\hline \hline No payments/gifts are paid & 0 \\
\hline \hline Don't know (spontaneous) & -9 \\
\hline \hline Refusal (spontaneous) & -8 \\
\hline
\end{tabular}

Figure 5: Questionnaire for dependent variables Corrupt(j30f) and CorSale(j7a). 
Table 11: Summary Statistics: Industries

\begin{tabular}{lccc}
\hline \hline & $(1)$ & & \\
& frequency & percentage & cum. percentage \\
\hline wholesale & 1214 & 24.32 & 24.32 \\
retail & 602 & 12.06 & 36.38 \\
other manufacturing & 597 & 11.96 & 48.34 \\
construction & 465 & 9.31 & 57.65 \\
fabricate metal products & 254 & 5.09 & 62.74 \\
food & 250 & 5.01 & 67.75 \\
machinery and equipment & 239 & 4.79 & 72.54 \\
chemicals & 235 & 4.71 & 77.24 \\
transport & 179 & 3.59 & 80.83 \\
it & 154 & 3.08 & 83.91 \\
hotel and restaurants & 146 & 2.92 & 86.84 \\
garments & 142 & 2.84 & 89.68 \\
electronics & 124 & 2.48 & 92.17 \\
plastics and rubber & 122 & 2.44 & 94.61 \\
non metallic mineral products & 110 & 2.20 & 96.81 \\
other services & 109 & 2.18 & 99.00 \\
basic metals & 28 & 0.56 & 99.56 \\
textiles & 22 & 0.44 & 100.00 \\
\hline Total & 4992 & 100.00 & \\
\hline \hline
\end{tabular}




\section{Working Paper Series}

ISSN 1211-3298

Registration No. (Ministry of Culture): E 19443

Individual researchers, as well as the on-line and printed versions of the CERGE-EI Working Papers (including their dissemination) were supported from institutional support RVO 67985998 from Economics Institute of the ASCR, v. v. i.

Specific research support and/or other grants the researchers/publications benefited from are acknowledged at the beginning of the Paper.

(c) Oleg Sidorkin and Dmitriy Vorobyev, 2015

All rights reserved. No part of this publication may be reproduced, stored in a retrieval system or transmitted in any form or by any means, electronic, mechanical or photocopying, recording, or otherwise without the prior permission of the publisher.

Published by

Charles University in Prague, Center for Economic Research and Graduate Education (CERGE) and

Economics Institute of the ASCR, v. v. i. (EI)

CERGE-El, Politických vězňu 7, 11121 Prague 1, tel.: +420 224005 153, Czech Republic.

Printed by CERGE-EI, Prague

Subscription: CERGE-EI homepage: http://www.cerge-ei.cz

Phone: + 420224005153

Email: office@cerge-ei.cz

Web: http://www.cerge-ei.cz

Editor: Marek Kapička

The paper is available online at http://www.cerge-ei.cz/publications/working_papers/.

ISBN 978-80-7343-344-4 (Univerzita Karlova. Centrum pro ekonomický výzkum a doktorské studium)

ISBN 978-80-7344-336-8 (Akademie věd České republiky. Národohospodářský ústav) 
CERGE-EI

P.O.BOX 882

Politických vězňů 7

11121 Praha 1

Czech Republic http://www.cerge-ei.cz 